ARTICLE

Received 16 Aug 2015 | Accepted 17 Mar 2016 | Published 19 Apr 2016

DOl: $10.1038 /$ ncomms11361

OPEN

\title{
NETosis and lack of DNase activity are key factors in Echis carinatus venom-induced tissue destruction
}

\author{
Gajanan D. Katkar', Mahalingam S. Sundaram¹, Somanathapura K. NaveenKumar', Basavarajaiah Swethakumar, \\ Rachana D. Sharma', Manoj Paul', Gopalapura J. Vishalakshi', Sannaningaiah Devaraja², Kesturu S. Girish',2 \\ \& Kempaiah Kemparaju ${ }^{1}$
}

Indian Echis carinatus bite causes sustained tissue destruction at the bite site. Neutrophils, the major leukocytes in the early defence process, accumulate at the bite site. Here we show that E. carinatus venom induces neutrophil extracellular trap (NET) formation. The NETs block the blood vessels and entrap the venom toxins at the injection site, promoting tissue destruction. The stability of NETs is attributed to the lack of NETs-degrading DNase activity in E. carinatus venom. In a mouse tail model, mice co-injected with venom and DNase 1, and neutropenic mice injected with the venom, do not develop NETs, venom accumulation and tissue destruction at the injected site. Strikingly, venom-induced mice tail tissue destruction is also prevented by the subsequent injection of DNase 1. Thus, our study suggests that DNase 1 treatment may have a therapeutic potential for preventing the tissue destruction caused by snake venom.

\footnotetext{
${ }^{1}$ Department of Studies in Biochemistry, University of Mysore, Manasagangothri, Mysuru 570006, India. ${ }^{2}$ Department of Studies and Research in Biochemistry, Tumkur University, Tumkuru 572103, India. Correspondence and requests for materials should be addressed to K.S.G.

(email: ksgbaboo@gmail.com) or to K.K. (email: kemparajuom@gmail.com).
} 
S nakebites affect millions of people worldwide and cause injury, disability and death. Annual epidemiology data have recorded $\sim 5.5$ million bites, including 0.4 million amputations and 0.125 million deaths ${ }^{1-3}$. However, the public health importance of snakebites has been neglected ${ }^{3}$. Thus, in 2009, the World Health Organization categorized snakebite as a 'Neglected tropical disease ${ }^{3}$. Snakebite causes both fatal systemic and local toxicities. The local toxicity is characterized by the continued tissue destruction, which predominantly results from viper bites. Although antivenom therapy has saved many lives, it has failed to inhibit viper bite-induced tissue destruction ${ }^{4}$. In addition, studies have demonstrated that Metzincin family matrix-degrading snake venom metalloproteases (SVMPs) ${ }^{5}$ and hyaluronidases (SVHYs) induce local tissue destruction ${ }^{6-8}$; unfortunately, their neutralization by natural and synthetic compounds has failed to reach the clinic ${ }^{9-11}$. This is not due to lack of neutralizing potency of the antivenoms or ineptness of the inhibitors, but rather to the rapid development of local pathology with an unknown cause, which prevents the therapeutic antibodies/inhibitors from accessing the damaged site ${ }^{1}$.

Echis species (saw-scaled/carpet vipers) envenomation is well known for producing tissue destruction at the bite site and accounts for the largest number of cases of mortality and morbidity resulting from snakebite in northern Africa and Asia ${ }^{10,12}$. Echis species venom is rich in SVMPs, which are multidomain haemorrhagic proteases that contain additional cysteine-rich and C-type lectin-like domains ${ }^{13,14}$. These additional domains are largely responsible for the recruitment of inflammatory cells that trigger inflammation ${ }^{14}$. Neutrophils are the first-line defence cells in innate immunity, and they infiltrate and accumulate at the bite site ${ }^{15}$; however, their role in tissue destruction remains unknown ${ }^{16}$. These cells quickly respond to foreign agents through phagocytosis and respiratory burst, but when required, they readily die by discharging their decondensed chromatin covered with cytotoxic and antimicrobial agents, known as neutrophil extracellular traps or NETs, in a processdubbed NETosis ${ }^{17,18}$. The defensive role of NETs/extracellular DNA in immobilizing and killing pathogens has been well documented ${ }^{17}$ and is termed as an ancient defence weapon ${ }^{19}$. Paradoxically, NETs also elicit collateral damage because of their associated cytotoxic components ${ }^{20-22}$. Thus, NETs work like a double-edged sword ${ }^{23}$. This led us to focus on and explore the role played by neutrophils in the tissue destruction induced by $E$. carinatus venom. As neutrophils accumulate at the site of venom injection, we hypothesized that the venom triggers NETosis. NETs may play a critical role in the entrapment and accumulation of venom toxins at the bite/injection site, which could be a trigger that accelerates tissue destruction.

Here we demonstrate that $E$. carinatus venom causes formation of NETs, resulting in the accumulation of venom toxins at the injection site and leading to continued tissue degradation. We also show that NETs could be degraded by externally added DNase 1, which could be a possible treatment for this type of snakebite.

\section{Results}

E. carinatus venom stimulates neutrophils to promote NETosis. We tested whether E. carinatus venom could induce NETosis in human neutrophils. The venom induced NET formation in both dose- and time-dependent manner, and the NETs were quantified using myeloperoxidase-DNA (MPO-DNA) capture ELISA (Fig. 1a, left and right) and Hoechst staining (Fig. 1b, left and right) assays. The venom-treated neutrophils showed a dosedependent increase in the expression of the peptidylarginine deiminase 4 (PAD4) enzyme (Fig. 1c, left), and this paralleled with the formation of citrullinated histone H3 (H3Cit; Fig. 1c, right) in western blot studies. Furthermore, the immunocytochemistry study revealed that $\mathrm{H} 3 \mathrm{Cit}$ and the extracellular DNA co-localize (Fig. 1d). The quantification of the H3Cit-positive neutrophils and their extruded DNA indicated that they were significantly increased compared with unstimulated neutrophils (Supplementary Fig. 1a,b). Phorbol 12-myristate 13-acetate (PMA)-treated neutrophils served as positive control. Scanning electron microscope analysis confirmed the NETosis, where thick bundles of chromatin fibres, NETs, emerging from and connecting different neutrophils were conspicuously visible compared with the intact, unstimulated neutrophils (Fig. 1e). We next examined the E. carinatus venom-induced dose-dependent reactive oxygen species (ROS) production in neutrophils (Supplementary Fig. 2). The venom-induced ROS production was decreased when neutrophils were pre-incubated with diphenyleneiodonium chloride (DPI) or dinitrophenol (DNP) or together (Fig. 2a). However, DNP decreased the ROS production more significantly than DPI, whereas in combination the effect was found to be additive (Fig. 2a). Similarly, the trend was paralleled with the quantity of NETs formation (Fig. 2b).

In the in vivo experiment, mice that were given injections of E. carinatus venom (lethal dose $e_{50}\left(\mathrm{LD}_{50}\right)$ is the amount of venom that causes 50\% mortality) into the tail were observed for 15 days. The appearance of haemorrhage and tissue destruction at the site of injection was noticed $\sim 1 \mathrm{~h}$ after venom injection. The tail exhibited severe haemorrhage and tissue destruction $8 \mathrm{~h}$ after venom injection compared with the control, which received phosphate-buffered saline (PBS; Supplementary Fig. 3a). The venom-injected tails were monitored and visually scored for injury for 15 days. The injured tails detached between days 10 and 15 (Supplementary Fig. 3b). Western blotting of the venominjected tail tissue homogenates revealed increased levels of $\mathrm{H} 3 \mathrm{Cit}$ and MPO that reached a maximum at $8 \mathrm{~h}$ and persisted even after the tail became necrotic (day 3 and onwards) and detached (day 10 and onwards; Fig. 3a). Tail tissue sections taken $8 \mathrm{~h}$ after venom injection showed the destruction and loss of integrity of the dermis and hypodermis, along with extruded DNA in the haematoxylin and eosin (H\&E) staining compared with the PBS-injected control tail tissue sections (Supplementary Fig. 3c). Furthermore, immunofluorescence images of the tail tissue sections were positive for Ly6G, H3Cit and extracellular DNA, indicating that NETosis occurred in the venom-injected tail tissue (Fig. 3b and Supplementary Fig. 3d). A confocal microscopy study confirmed the existence of NETs in the venom-injected tail tissues, as evidenced by the co-localization of lactoferrin, $\mathrm{H} 3 \mathrm{Cit}$ and extracellular DNA (Fig. 3c and Supplementary Fig. 4). However, H3Cit antibody also showed some nonspecific binding in mice tail tissues (Supplementary Fig. 4).

NETs block blood vessels and capture E. carinatus venom. $\mathrm{H} \& \mathrm{E}$-stained tail tissue sections obtained $8 \mathrm{~h}$ after venom injection showed that the veins and capillaries (Fig. 4a) were blocked owing to the accumulation of NETs. Immunohistochemistry of the tail tissue sections further confirmed the accumulation and blockage of artery (Fig. 4b) and vein (Fig. 4c) by the NETs, as evidenced by the co-localization of Ly6G, H3Cit and extracellular DNA. Furthermore, E. carinatus venom accumulated in these tissue sections, even at $8 \mathrm{~h}$ after the venom injection, as demonstrated using a rabbit polyclonal antivenom raised against E. carinatus venom (Fig. $4 \mathrm{~d}$ ).

Immunocytochemistry revealed that the NETs captured the venom, as evidenced by the co-localization of the venom toxins and NETs (Fig. 5a). The DNA-venom capture ELISA technique was employed to demonstrate the interaction between the NETs and the E. carinatus venom. The formation of the NET-venom 
a
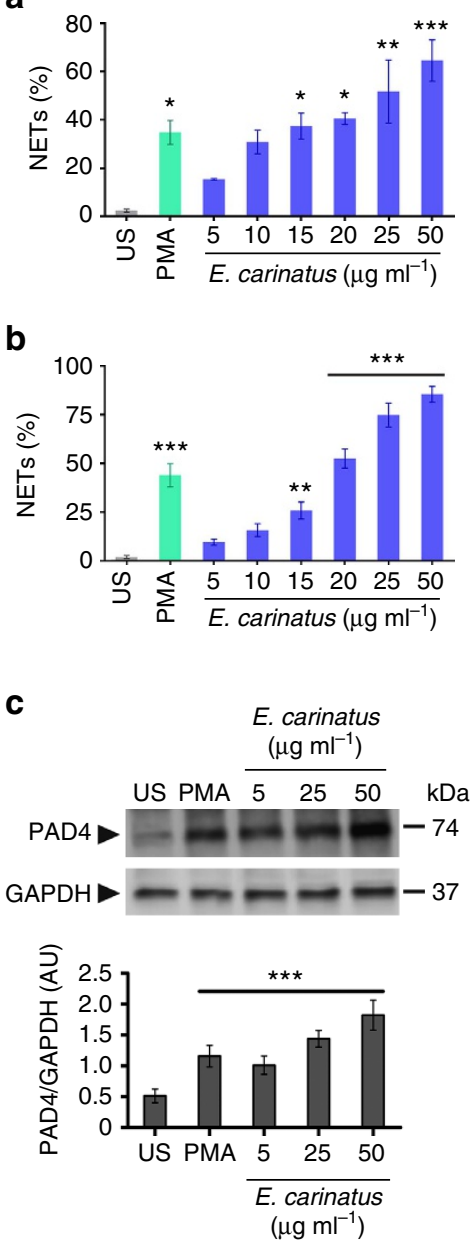
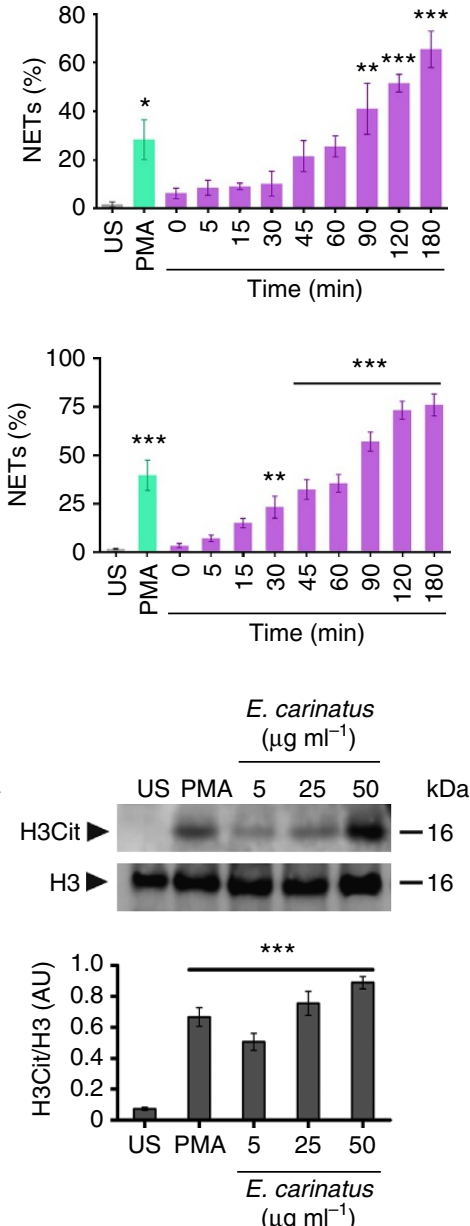

$\left(\mu \mathrm{g} \mathrm{ml}^{-1}\right)$

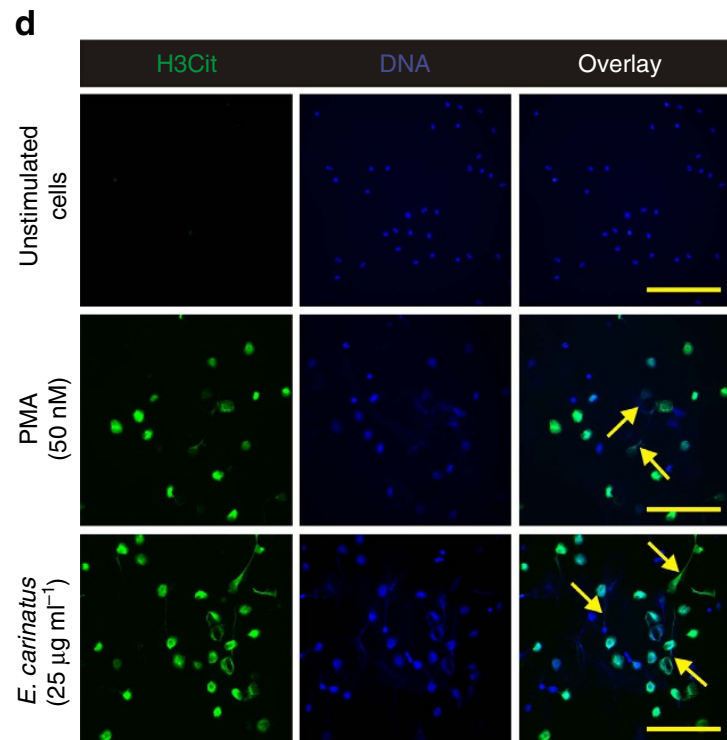

e
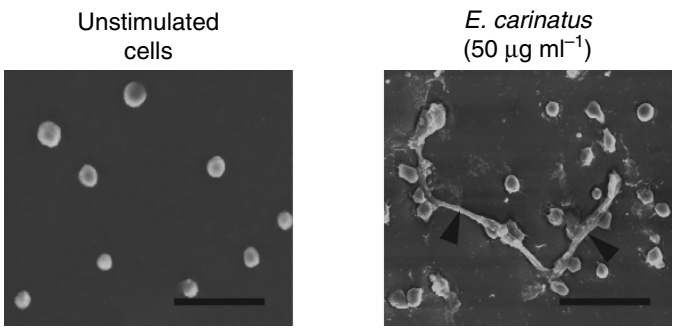

E. carinatus

Figure 1 | E. carinatus venom stimulates ex vivo NETosis. E. carinatus venom-stimulated NET formation was quantified using (a) MPO-DNA capture ELISA and (b) Hoechst staining in dose- (left) and time-dependent (right) assays. The results are expressed as the percent increase relative to unstimulated cells (US); mean \pm s.e.m. $(n=6)$. ${ }^{\star} P<0.05,{ }^{\star \star} P<0.01,{ }^{\star \star \star} P<0.001$ versus US; one-way analysis of variance (ANOVA), followed by Dunnett's post-hoc test. PMA (50 nM) served as a positive control. (c) Western blot analysis of PAD4 expression (top, left) and the presence of H3Cit (top, right) in E. carinatus venom-treated neutrophils. PAD4 expression was normalized to GAPDH expression (bottom, left), and H3Cit levels were normalized to H3 levels (bottom, right). AU, arbitrary units; $\mathrm{H} 3 \mathrm{Cit}$, citrullinated histone 3; $\mathrm{H} 3$, histone 3 ; US, unstimulated cells. The data are presented as mean $\pm \mathrm{s} . \mathrm{e} . \mathrm{m}$. ( $n=4$ ). ${ }^{\star \star \star} P<0.001$ versus US; one-way ANOVA, followed by Dunnett's post-hoc test. PMA ( 50 nM) served as a positive control. The PVDF membranes were cut based on molecular weight of respective protein using protein molecular weight marker and then probed with respective antibodies. (d) Representative immunofluorescence images of neutrophils/NETs. The neutrophils were exposed to $E$. carinatus venom ( $25 \mu \mathrm{mg}{ }^{-1}$ ) for $2.5 \mathrm{~h}$ at $37^{\circ} \mathrm{C}$. Yellow arrows indicate NETs. $(n=4)$ Scale bars, $100 \mu \mathrm{m}$. PMA (50 nM) served as a positive control. (e) Scanning electron microscopy images showing unstimulated neutrophils (left) and E. carinatus venom-stimulated neutrophils, which displayed NETs with thick bundles of fibres (black arrowheads; right). ( $n=4$ ) Scale bars, $30 \mu \mathrm{m}$.

complex increased with the increasing amounts of venom (Fig. 5b). The interaction between the DNA and the venom was further analysed using native polyacrylamide gel electrophoresis (PAGE), where the addition of venom to DNA retarded DNA mobility in a dose-dependent manner (Fig. 5c). The DNA-venom complex was dissociated using a DNA isolation protocol and analysed by native PAGE (Fig. 5c). Then, the DNA-venom complex was studied for its lethal potency using independent groups of mice that received the DNA-venom complex prepared using an $\mathrm{LD}_{50}$ or LD dose of the venom (venom/DNA: 1:1, w/w; Fig. 5d). Neither group exhibited mortality, while the groups that received $\mathrm{LD}_{50}$ and $\mathrm{LD}$ of venom alone exhibited $50 \%$ and $100 \%$ mortality, respectively. In contrast, E. carinatus venom failed to induce tail tissue damage in neutropenic mice (Fig. 6a). The tail injury score was decreased by approximately eightfold in neutropenic mice compared with the venom-injected control mice (Fig. 6b). Western blot analysis of tail tissue homogenates from the venom-injected neutropenic mice showed no sign of H3Cit signals (Fig. 6c). H\&E staining of tail tissue sections from the venom-injected neutropenic mice showed an absence of neutrophils and, hence, extracellular DNA compared with the venom-injected normal mice (Fig. 6d). Immunohistochemistry further confirmed the lack of neutrophils and NETs, as the sections were negative for Ly6G and H3Cit (Fig. 6e). Whereas the group of neutropenic mice that received the $\mathrm{LD}_{50}$ dose of venom exhibited $100 \%$ mortality (Supplementary Fig. 5). As DNA is the backbone of NETs, the E. carinatus venom-induced stable NETosis was our impetus to test the DNase activity of the venom. We found that the venom failed to degrade herring sperm DNA, even after exhaustive incubation for $24 \mathrm{~h}$ (Supplementary Fig. 6).

DNase 1 prevents $E$. carinatus venom-induced NETosis. In in vivo studies, co-injection of DNase 1 prevented the E. carinatus 
a

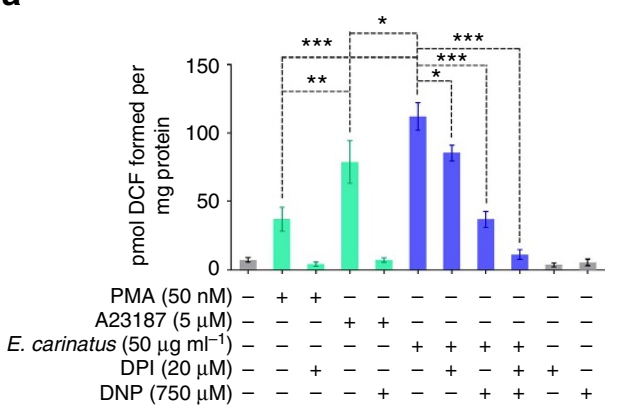

b

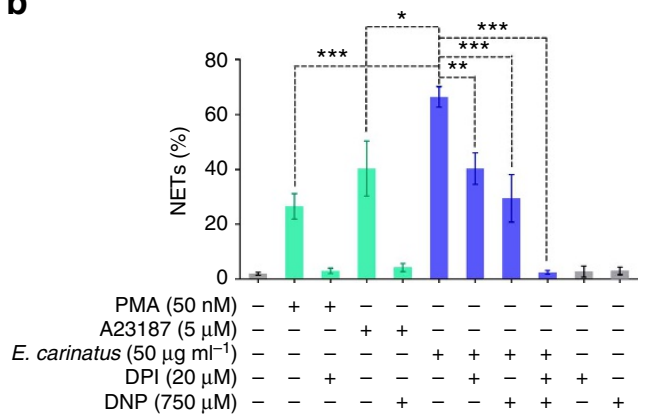

Figure 2 | E. carinatus venom-mediated NETosis is both NOX-dependent and NOX-independent. (a) Represents the level of ROS in neutrophils incubated with PMA, A23187 or E. carinatus venom in the presence or absence of DPI $(20 \mu \mathrm{M})$ or DNP $(750 \mu \mathrm{M})$ or both DPI $(20 \mu \mathrm{M}), \mathrm{DNP}(750 \mu \mathrm{M})$. The data are presented as mean \pm s.e.m. $(n=4) .{ }^{\star} P<0.05,{ }^{\star \star} P<0.01,{ }^{\star \star \star} P<0.001$; one-way analysis of variance followed by Bonferroni post-hoc test. (b) Represents NET release measured using MPO-DNA capture ELISA in neutrophils incubated with PMA, A23187 or E. carinatus venom in the presence or absence of DPI $(20 \mu \mathrm{M})$ or DNP $(750 \mu \mathrm{M})$ or both DPI $(20 \mu \mathrm{M})$ DNP $(750 \mu \mathrm{M})$. The data are presented as mean \pm s.e.m. $(n=4) .{ }^{\star} P<0.05,{ }^{\star \star} P<0.01$, ${ }^{\star \star \star} P<0.001$; oneway ANOVA, followed by Bonferroni post-hoc test.

venom-induced tail tissue damage in a dose-dependent manner (Supplementary Fig. 7a). However, the tissue-damaging property of the venom was not altered by co-injection with actin pretreated DNase 1 (Supplementary Fig. 7a). The western blot study revealed that $\mathrm{H} 3 \mathrm{Cit}$ (Fig. 7a) and venom (Fig. 7b) were not present in tail tissue homogenates from mice injected with both venom and DNase 1 , whereas the homogenates from mice injected with venom alone contained both H3Cit (Fig. 7a) and venom (Fig. 7b). Venom accumulation was further demonstrated using immunofluorescence of the tail tissue sections (Fig. 7c). Although the mice injected with both venom and DNase 1 did not show any signs of local tissue damage, interestingly, the mice died much faster than if they were injected with venom alone (Fig. $7 \mathrm{~d}$ and Supplementary Fig. 7b).

In the challenge study, the tail injury score (Fig. 8a) and photographs of representative mice (Fig. 8b) revealed that when DNase 1 was injected at different time intervals after the venom $\left(\mathrm{LD}_{50}\right)$ injection (30-180 min), the mice tails showed initial signs of haemorrhage on days 1 and 2, and recovered on days 5-7, exhibiting normal tail morphology without an increase in lethality. Conversely, in the absence of the DNase 1 treatment, intense haemorrhage and wound formation led to the detachment of the affected tail portion between days 10 and 15 (Fig. 8a,b). Moreover, when serum was incubated with E. carinatus venom, the serum DNase activity was not inhibited, as evidenced by the nearly equal zone of clearance in serum alone and in serum incubated with the increasing doses of E. carinatus venom (Supplementary Fig. 8).

To determine whether venom from another snake species, N. naja, induces NETosis, we used MPO-DNA capture ELISA assay. We did observe NETosis at lower doses of the venom, but it was not observed at higher doses or with prolonged incubation periods (Fig. 9a). Western blot study using a rabbit polyclonal antivenom for $N$. naja venom showed that the venom did not accumulate at the injection site (Fig. 9b). This was further confirmed by the immunohistochemistry study, in which tail tissue sections from venom-injected mice did not show an accumulation of venom at the injection site. However, in mice injected with actin pre-treated $N$. naja venom, the tail tissue sections exhibited an accumulation of the venom (Fig. 9b,c). Furthermore, the actin pre-treated $N$. naja venom failed to induce lethal toxicity, as all of the experimental mice survived (Fig. 9d). Finally, when tested for DNase activity, the $N$. naja venom dose-dependently hydrolysed calf thymus DNA, whereas actin pre-treated venom failed to hydrolyse DNA (Supplementary Fig. 9).

\section{Discussion}

E. carinatus induces intense tissue destruction at the bite site, with symptoms such as oedema, haemorrhage and tissue destruction ${ }^{10,24}$. Although neutrophil infiltration has been demonstrated at the site of a viper bite/venom injection ${ }^{15}$, it has not been thoroughly investigated ${ }^{8}$. This study deciphers the cellular mechanism of tissue destruction by the E. carinatus venom and suggested a possible therapeutic approach for snakebite management. We show that the venom-stimulated neutrophils undergo NETosis and that the resulting NETs block the blood vessels to prevent the venom from entering the circulation, resulting in venom accumulation and tissue destruction at the injection site. This effect was reversed by the administration of DNase 1 .

Neutrophils are the first-line defence cells and effectively capture pathogens by NETosis ${ }^{17}$. NETosis occurs via both the NOX-dependent and NOX-independent pathways ${ }^{25}$. Our study suggests that $E$. carinatus venom stimulated the neutrophils to undergo NETosis both in vitro and in vivo. E. carinatus venomstimulated ROS production and NETosis were significantly decreased in the presence of DPI (NOX inhibitor) and DNP (uncoupler of oxidative phosphorylation and electron transport) indicating the induction of both the NOX-dependent and NOXindependent pathways. Induction of both pathways is likely due to the presence of various toxins in E. carinatus venom that affects several cellular pathways. Some strains of Staphylococcus aureus and lipid mediator hepoxilin A3 induce NETosis through both the NOX-dependent and NOX-independent patways ${ }^{26-28}$ Several recent studies have demonstrated that E. carinatus venom induced oxidative stress in both ex vivo and in vivo experiments ${ }^{10,29}$. NETosis is marked by increased PAD4 expression, which triggers chromatin de-condensation through deimination of arginine in $\mathrm{H} 3$ to form citrulline $(\mathrm{H} 3 \mathrm{Cit})^{30,31}$. Thus, the results of the western blot shows increased expression of PAD4 and the appearance of H3Cit in human neutrophils support the hypothesis that the E. carinatus venom induces NETosis. The rapid increase in PAD4 levels in neutrophils could be due to $E$. carinatus venom-stimulated NOX-independent pathway ${ }^{25,32}$. We show that $E$. carinatus venom does not contain bacteria, which rules out the role of bacterial contamination in driving neutrophils into NETosis (Supplementary Fig. 10). The detection of NETosis markers, such as Ly6G, lactoferrin and H3Cit, in venom-injected tail tissue sections confirmed NETosis in vivo.

Furthermore, the sections exhibited blood vessel obstruction due to the accumulation of blood clots, including NETs. 
a
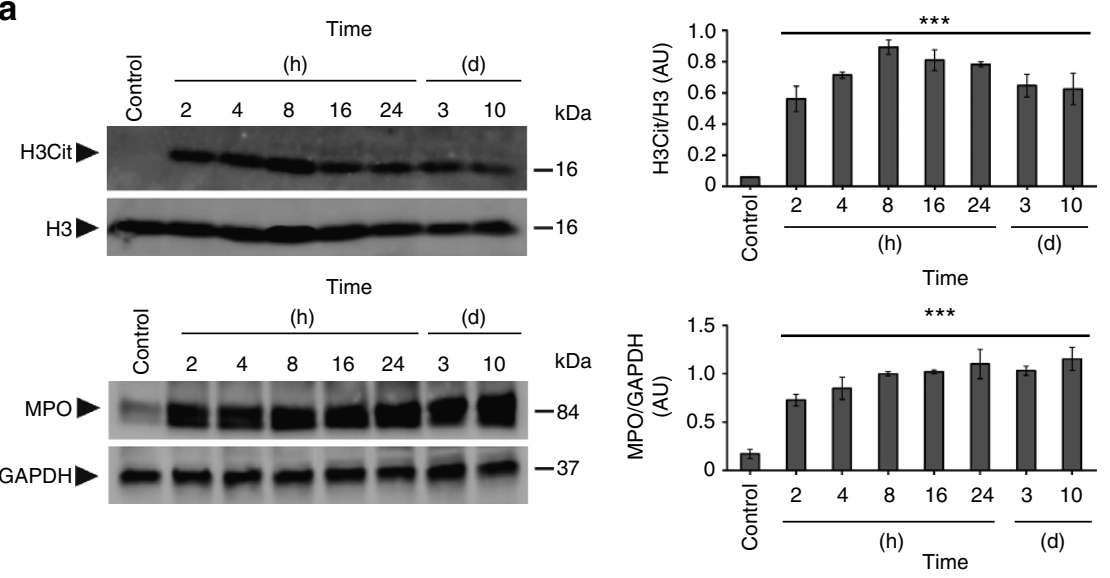

b

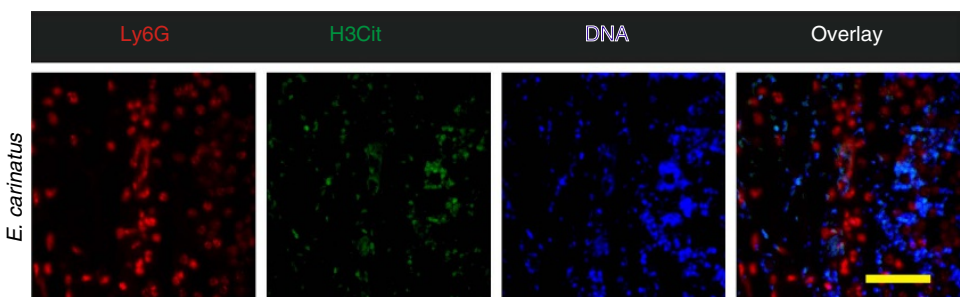

C
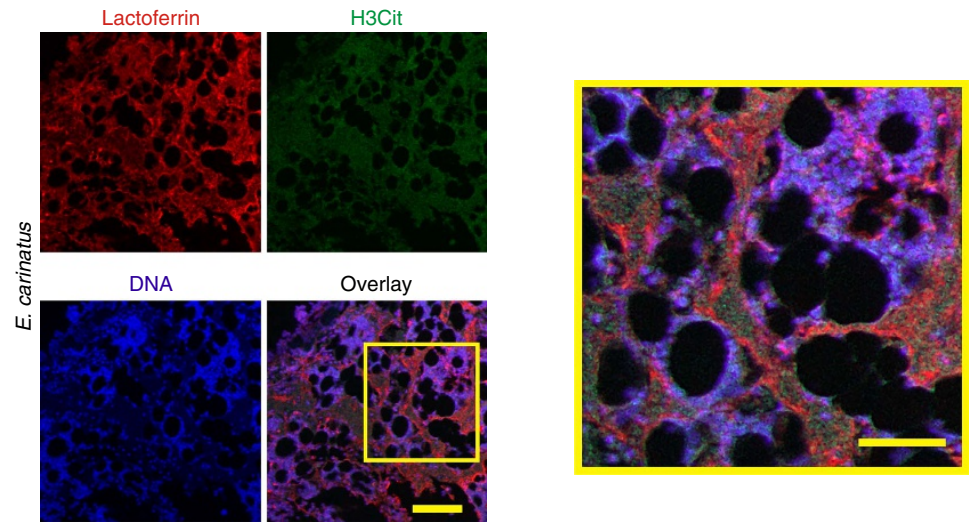

Figure 3 | E. carinatus venom stimulates in vivo NETosis. (a) Representative western blot of the time course of H3Cit and MPO appearance in E. carinatus venom ( $\left(D_{50}\right.$ )-injected mouse tail tissue (left) and quantification of the H3Cit levels compared with the H3 levels (top, right) and MPO level compared to $\mathrm{GAPDH}$ (bottom, right). AU, arbitrary units; $\mathrm{H} 3 \mathrm{Cit}$, citrullinated histone 3; H3, histone 3; MPO, myeloperoxidase. The data are presented as mean \pm s.e.m; Student's $t$-test, ${ }^{\star \star \star} P<0.001$ versus control; $n=4$ for the control, 2, 4, 8 and $16 \mathrm{~h}$ samples; $n=5$ for $24 \mathrm{~h}$, day 3 and day 10 samples. The PVDF membranes were cut based on molecular weight of respective protein using protein molecular weight marker and then probed with respective antibodies.

(b) Representative immunofluorescence images of mouse tail tissue $8 \mathrm{~h}$ after E. carinatus venom $\left(\mathrm{LD}_{50}\right)$ injection, focused beneath the epithelial layer. Scale bar, $100 \mu \mathrm{m}(n=4)$. (c) Representative confocal image of $E$. carinatus venom $\left(L D_{50}\right)$-injected mouse tail tissues focused beneath the epithelial layer. The area enclosed by the yellow box is magnified and shown on the right. Scale bars, $100 \mu \mathrm{m}$ (left), $50 \mu \mathrm{m}$ (right); $n=3$.

E. carinatus venom is a pro-coagulant ${ }^{33}$ and promotes fibrin clot formation ${ }^{10,34}$. Moreover, NETs also promote fibrin clot formation ${ }^{35,36}$. NET-associated clots are more resistant to mechanical forces and enzymatic digestion ${ }^{35,37}$; thus, the blood vessels remained blocked, even after $8 \mathrm{~h}$ of venom injection, despite the fibri(noge)nolytic activity of E. carinatus venom ${ }^{10,24}$. However, further detailed investigation is warranted to understand the interactions between NETs and fibrin clots. The blockage of blood vessels prevents the easy entry of the venom into the circulation and causes its accumulation at the injection site. The accumulated venom is a cocktail of several enzymatic and non-enzymatic toxins, predominantly the extracellular matrix (ECM)-degrading haemorrhagic SVMPs and SVHYs. SVMPs degrade structural proteins, including collagens, laminin and fibronectin molecules $5,38,39$, whereas SVHYs degrade the structural glycosaminoglycan hyaluronic acid ${ }^{6,8,40}$. Thus, the loss of ECM integrity destabilizes the tissues and the basement membrane of blood vessels. In addition, NET-associated histones can damage endothelial cells ${ }^{20,21,23}$. Furthermore, NET-associated neutrophil elastase is a highly stable broadspectrum protease that can cause further ECM damage $20,22,23,30$ In a recent study, NETosis was shown to cause delayed wound healing in diabetic patients ${ }^{32}$. Therefore, E. carinatus venominduced NETosis not only restricts the venom to the bite site and promotes tissue destruction but also blocks the blood flow to the tissues and cells that are distal to the bite site. Increased NET formation or impaired NET clearance is detrimental, as demonstrated in chronic inflammatory disorders, including vasculitis, psoriasis, preeclampsia, atherosclerosis, systemic lupus erythematosus and gout ${ }^{23,41-43}$. 
a

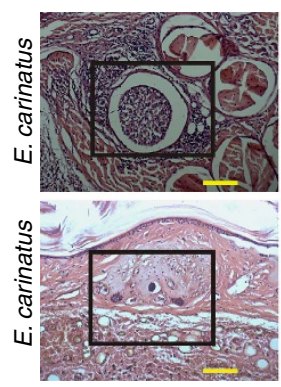

C

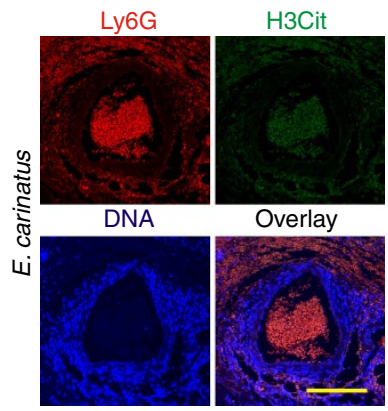

b
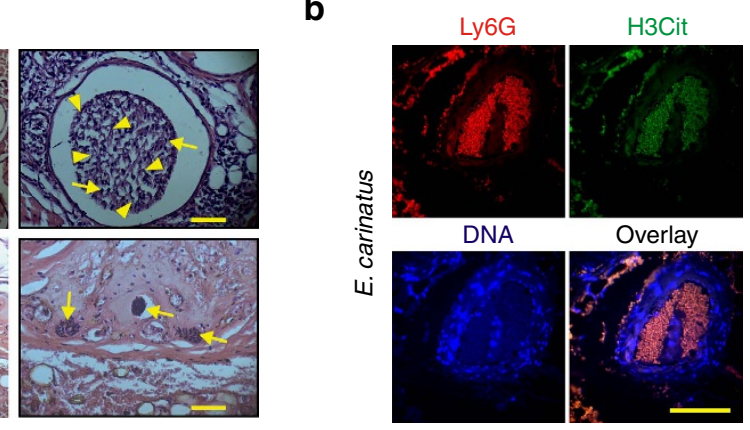

d

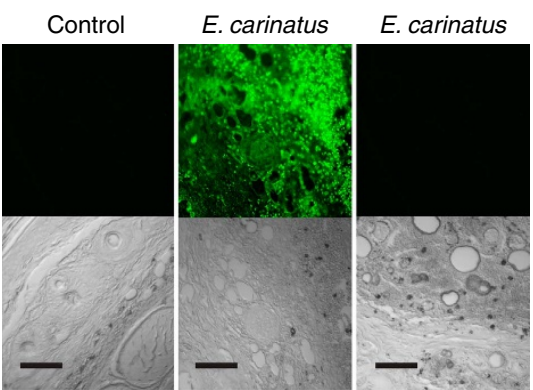

Figure 4 | NETs block blood vessels, leading to accumulation of $\boldsymbol{E}$. carinatus venom. (a) Images of H\&E-stained mouse tail tissue $8 \mathrm{~h}$ after $E$. carinatus venom $\left(\mathrm{LD}_{50}\right.$ ) injection show clot formation in the mouse tail vein (top, left) and blocked blood capillaries (bottom, left). The respective enlarged images are shown on the right. Scale bars, $50 \mu \mathrm{m}$ (left), $100 \mu \mathrm{m}$ (right). Yellow arrowheads indicate NETs and yellow arrows indicate neutrophils. Immunofluorescence image of the mouse $(n=4)$. (b) tail artery and $(\mathbf{c})$ vein $8 \mathrm{~h}$ after $E$. carinatus venom $\left(\mathrm{LD}_{50}\right)$ injection. Scale bars, $100 \mu \mathrm{m}(n=4)$. (d) Immunofluorescence images show the accumulation of venom in E. carinatus venom ( $L D_{50}$ )-injected mouse tail tissue section (top row, middle), section with a secondary antibody control (top row, right) and section of PBS-injected tail tissue, which served as a control (top, left). The corresponding differential interference contrast (DIC) images of the respective tissues are also shown (bottom row). Scale bars, $100 \mu \mathrm{m}(n=4)$.

Chromatin is an ancient defence weapon of the innate immune system $^{19}$; it is known to form a complex net that enmeshes and kills bacteria, fungi, viruses and other parasites ${ }^{17}$. We demonstrate that the venom-induced NETs capture venom toxins. The negative charge in the NETs ${ }^{44}$ could sequester the positively charged venom toxins such as basic $\mathrm{PLA}_{2} \mathrm{~S}$, 3FTx and SVMPs ${ }^{45-48}$. The successful recovery of DNA from the DNA-venom complex suggests that the interaction between the DNA and venom toxins was non-covalent. Surprisingly, the lethality studies showed that the lethal potency of the venom was reduced when it formed complex with the DNA. This was attributed to the sequestration and inhibition of the positively charged venom toxins by the NETs/DNA. We reasoned that the depletion of the neutrophils and, hence, the NETs would result in decreased venom-induced tissue destruction and increased lethal potency. Indeed, in neutropenic mice, the venom did not induce haemorrhage and tissue destruction at the injection site, but caused $100 \%$ mortality even at the $\mathrm{LD}_{50}$ dose of venom. Of note, and as discussed above, although E. carinatus venom-induced NETosis is detrimental, it is an adaptive immune response that restricts the entry of $E$. carinatus venom into the circulation and protect from its lethal systemic toxicity.

The stability of the NETs is due to the lack of DNase activity in the E. carinatus venom and the inability of serum DNase to clear the large accumulated NETs at the injection site. We ruled out the possible inhibition of serum DNase by the E. carinatus venom. Thus, we tested whether DNase 1 could clear the NETs. As anticipated, co-injection of venom and DNase 1 prevented haemorrhage and local tissue damage, but also increased the lethal potency of the venom by improving penetration of the venom into the circulation. This effect was neutralized by antivenom administration. Surprisingly, in the challenge study, all the mice survived when DNase 1 was administered 30-180 min after venom injection. This mitigation of the lethal potency of the venom could be due to the formation of the NETs/DNA-venom complex. We postulate that venom initially stimulates NETosis of the accumulated neutrophils. Eventually, the negatively charged NETs/DNA fibres form complexes with the positively charged venom toxins such as basic PLA $\mathrm{A}_{2} \mathrm{~s}$, 3FTxs and SVMPs and entrap them. Further, it is likely that the negatively charged NETs/DNA would chelate metal ions ${ }^{49}$ such as $\mathrm{Zn}^{2+}$ and $\mathrm{Ca}^{2+}$ thereby inhibiting SVMPs and venom $\mathrm{PLA}_{2} \mathrm{~S}$, respectively ${ }^{46,48,50}$. Although the NETs/DNA fibres are degraded by the administered DNase 1 , it is possible that the small DNA fragments remained in complex with the venom toxins keep them inactive. However, further studies are required to delineate the precise molecular mechanism(s) at play. NET clearance is essential for the wound-healing process ${ }^{32}$. Our present findings are complemented by recent studies showing that DNase 1 treatment accelerated wound resolution in diabetic and wild-type mice $^{32}$ and increased NET clearance by macrophages in vitro 51 . In contrast to the E. carinatus venom, which is known for its ability to induce haemorrhage and local tissue destruction, the $N$. naja venom lacks these effects ${ }^{52}$. This is most likely due to the fact that the N. naja venom contains high levels of DNase activity and this degrades NETs and prevents the venom from accumulating at the injection site, as the inhibition of DNase activity not only resulted in venom accumulation at the injection site but also abolished the venom's lethality. In addition, despite the venom accumulation at the injection site, there was no local tissue destruction. This is likely due to the fact that $N$. naja venom lacks ECM-degrading haemorrhagic SVMPs ${ }^{52}$.

In summary, the results indicate that E. carinatus venom induces the formation of stable NETs owing to its lack of DNase 
a
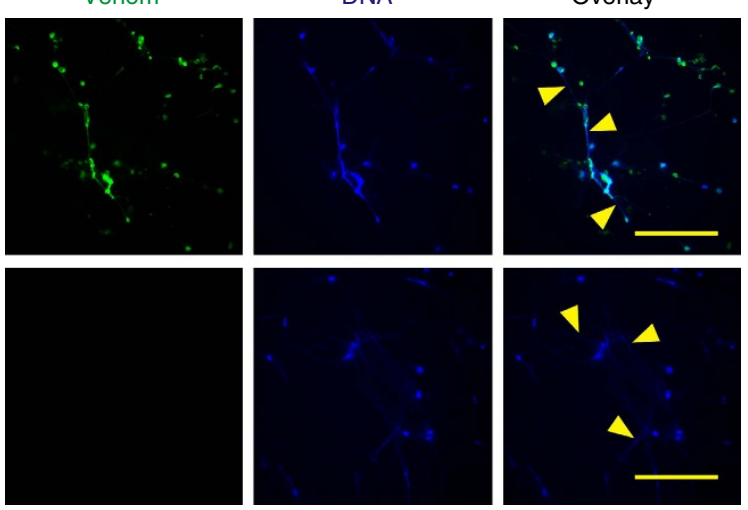

C

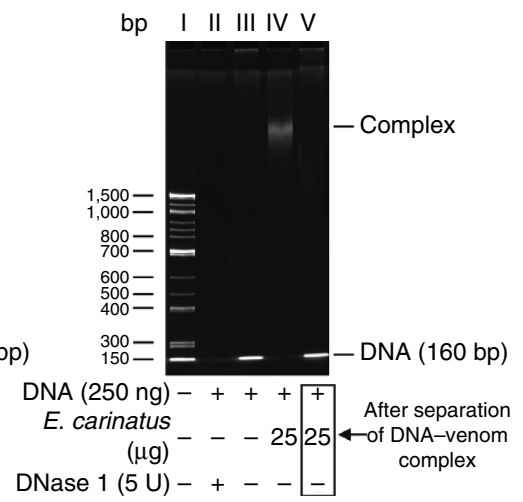

b

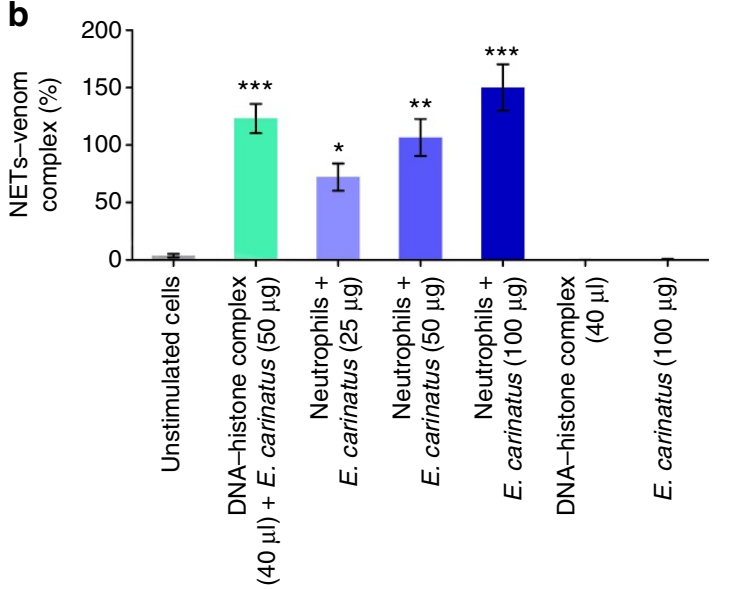

d

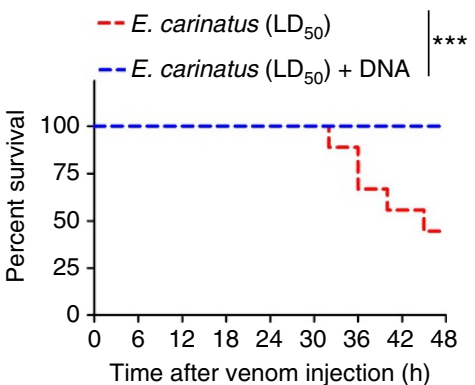

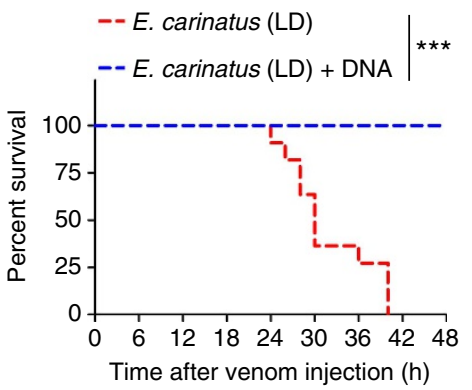

Figure 5 | NETs capture E. carinatus venom toxins. (a) Representative immunofluorescence image of neutrophils exposed to $E$. carinatus venom $\left(50 \mathrm{\mu g} \mathrm{ml}^{-1}\right)$ for $2.5 \mathrm{~h}$; the venom was detected using rabbit polyclonal antibody against $E$. carinatus venom followed by an AlexaFluor 488 -conjugated goat anti-rabbit antibody along with DNA stained by Hoechst stain (top row). The AlexaFluor 488-conjugated goat anti-rabbit secondary antibody control (bottom row). Yellow arrow heads indicate NETs. Scale bars, $100 \mu \mathrm{m}(n=4)$. (b) The NET-venom complex was quantified using the DNA-venom capture ELISA assay. The results are expressed as a percent increase with respect to the unstimulated cells. The data are presented as mean $\pm \mathrm{s}$.e.m. $(n=4)$. ${ }^{\star} P<0.05,{ }^{\star \star} P<0.01,{ }^{\star \star \star} P<0.001$ versus the unstimulated cells; one-way analysis of variance, followed by Dunnett's post-hoc test. (c) Native PAGE (7.5\%) showing the interaction between DNA and E. carinatus venom (left), as demonstrated by the dose-dependent retardation of the bands. Marker (lane I), $250 \mathrm{ng}$ DNA (lane II), $250 \mathrm{ng}$ DNA $+5 \mu \mathrm{g}$. carinatus venom (lane III), $250 \mathrm{ng}$ DNA $+25 \mu \mathrm{g}$. carinatus venom (lane IV) and $250 \mathrm{ng}$ DNA $+50 \mu \mathrm{g}$ E. carinatus venom (lane V). Recovery of DNA from the DNA-venom complex (right). Marker (lane I), 250 ng DNA + 5 U DNase 1 (lane II), 250 ng DNA (lane III), $250 \mathrm{ng}$ DNA $+25 \mu \mathrm{g}$ E. carinatus venom (lane IV) and recovered DNA from DNA + E. carinatus venom complex (lane V); $n=3$. (d) Kaplan-Meier survival curves show that the lethal potency of the $E$. carinatus venom is inhibited when it is incubated with DNA: $E$. carinatus venom, $L D_{50}(r e d$ line, left) and LD (red line, right), and $E$. carinatus venom incubated with DNA for $10 \mathrm{~min}$ at $37^{\circ} \mathrm{C}$ (blue line, both left and right); $n=10$. ${ }^{\star \star \star} P<0.001$. Log-rank test.

activity. These NETs trap the venom toxins and thereby promote tissue destruction at the injection/bite site. The dense NETs and the blood clots formed in the damaged tissues and capillaries hinder the free flow of blood and prevent the antivenom from reaching the damaged site. This study presents (i) the role of NETosis in E. carinatus venom-induced tissue destruction, (ii) a convenient mouse tail model to study viper venom-induced tissue destruction, (iii) the role of DNase activity in venom toxicity and (iv) provides a lead for designing new strategies for the possible use of DNase 1 in the management of E. carinatus venominduced tissue destruction. This study could also drive future studies to understand and uncover the molecular mechanisms associated with other venomous bites that cause similar pathological conditions. However, further detailed and systematic investigations in human subjects are needed to validate these findings before they are implemented in the clinic.

\section{Methods}

Animals. Adult Swiss albino mice (8- to 10-week-old male or female) weighing 20-25 g were obtained from the Central Animal House Facility, Department of
Zoology, University of Mysore, Mysuru, India. New Zealand albino female rabbits (6-month-old) weighing 1.5-2 kg were obtained from the Department of Livestock Production and Management, Veterinary College, Bengaluru, India. The animal experiments were approved by the Institutional Animal Ethical Committee, University of Mysore, Mysuru (Approval numbers: UOM/IAEC/20/2012 and UOM/IAEC/09/2013). During all experiments, animal care and handling were in accordance with the guidelines of the Committee for the Purpose of Control and Supervision of Experiments on Animals (CPCSEA).

Humans. Human blood was drawn from the antecubital veins of healthy adult volunteers who provided written informed consent, as per the guidelines of the Institutional Human Ethical Committee, University of Mysore, Mysuru. All the experiments were approved by the Institutional Human Ethical Committee, University of Mysore, Mysuru (Approval number: IHEC-UOM No. 47Res/2014-15) and conducted in accordance with the ethical guidelines.

Reagents. The E. carinatus and N. naja venoms were purchased from Irula Co-operative Society Ltd., Chennai, India. The calf thymus DNA, DMEM, Histopaque-1077, Ponceau stain, actin from bovine muscle, protease inhibitor cocktail, protein A agarose, dextran (molecular weight $\sim 100 \mathrm{kDa}$ ), PMA, bovine serum albumin, human serum albumin (HSA), calcium ionophore (A23187), $2^{\prime}, 7^{\prime}$-dichlorofluorescein diacetate (DCFDA), DPI, DNP, Cell Death Detection ELISA $^{\text {PLUS }}$ (Version 14, Roche Diagnostics), and Freund's complete and 
a

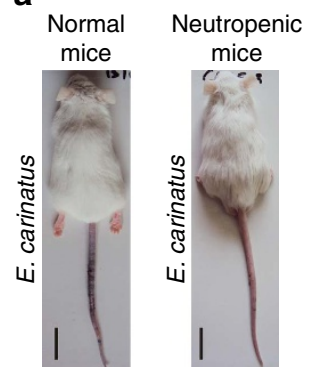

b

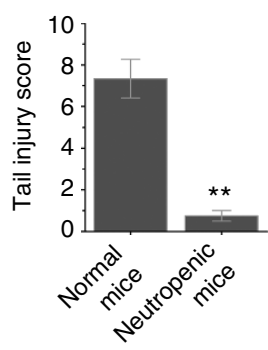

C

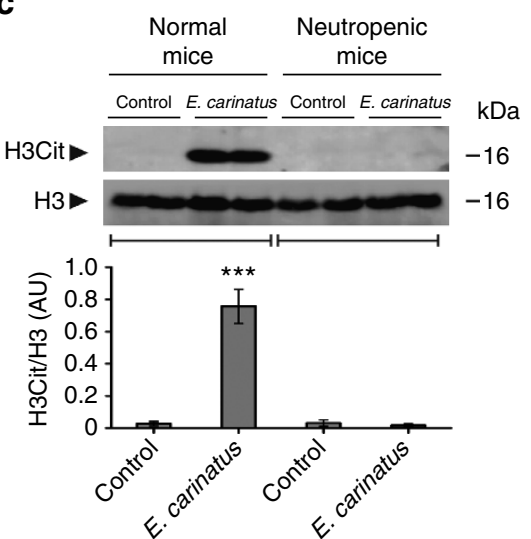

d

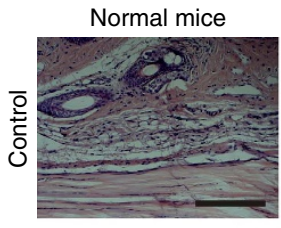

Normal mice

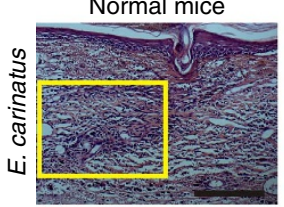

e

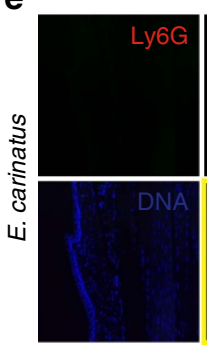

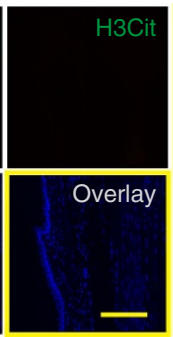

Neutropenic mice
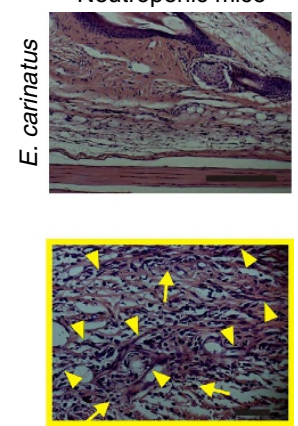

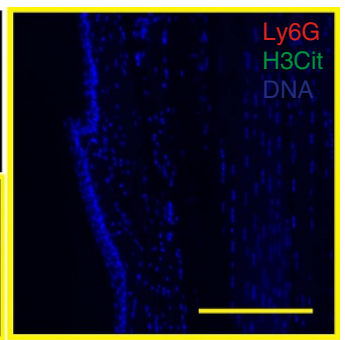

Figure 6 | E. carinatus venom does not induce local tissue damage or NETosis in neutropenic mice. (a) Representative photographs of mice $8 \mathrm{~h}$ after E. carinatus venom $\left(\mathrm{LD}_{50}\right)$ injection in the tail show intense venom-induced wound in the tail of a normal mouse (left), but no haemorrhage in a neutropenic mouse (right). Scale bars, $2 \mathrm{~cm}$. $(n=10)$. (b) The corresponding tail injury score $8 \mathrm{~h}$ after the $E$. carinatus venom $\left(\mathrm{LD}_{50}\right)$ injection is shown in a bar graph. The data are presented as mean \pm s.e.m. $n=6$ venom-injected normal mice; $n=10$ venom-injected neutropenic mice. ${ }^{\star \star} P<0.01$; Student's $t$-test. (c) Western blot analysis of the appearance of $\mathrm{H} 3 \mathrm{C}$ it (top) in tail tissue homogenates taken from normal and neutropenic mice $8 \mathrm{~h}$ after $E$. carinatus venom $\left(\mathrm{LD}_{50}\right)$ injection. The quantification of $\mathrm{H} 3 \mathrm{C}$ it levels compared with $\mathrm{H} 3$ levels is shown (bottom). $\mathrm{AU}$, arbitrary units; $\mathrm{H} 3 \mathrm{Cit}$, citrullinated histone 3;

$\mathrm{H} 3$, histone 3. The data are presented as mean \pm s.e.m. $(n=4) .{ }^{\star \star \star} P<0.001$ versus the normal control mice; one-way analysis of variance, followed by Dunnett's post-hoc test. The PVDF membranes were cut based on molecular weight of respective protein using protein molecular weight marker and then probed with respective antibodies. (d) H\&E-stained tail tissue sections from neutropenic (top right) and normal mice (bottom left) injected with E. carinatus venom $\left(\mathrm{LD}_{50}\right)$; the yellow portion is enlarged and shown on the right. Tissue from PBS-injected normal mice is also shown (top, left). Scale bars, $100 \mu \mathrm{m}$. $(n=4)$. (e) Representative immunofluorescence images of neutropenic mouse tail tissue $8 \mathrm{~h}$ after $E$. carinatus venom $\left(L_{50}\right)$ injection, focused beneath the epithelial layer. Scale bars, $100 \mu \mathrm{m}(n=4)$.

incomplete adjuvants were procured from Sigma Chemicals. DNase 1 was purchased from Boehringer Ingelheim. The anti-histone H3 antibody (Cat. no. SC-10809) was obtained from Santa Cruz Biotechnology, Inc. Hoechst 33342 (Cat. no. H3570) was obtained from Life Technologies. AlexaFluor 488-conjugated AffiniPure Goat Anti-Rabbit IgG (H + L) (Cat. no. 111-545-003), AlexaFluor 647-conjugated AffiniPure Goat Anti-mouse IgG (H + L) (Cat. no. 115-605-003) were purchased from Jackson Immuno Research Laboratories, Inc. The AlexaFluor 647-conjugated anti-mouse Ly 6G antibody (clone 1A8; Cat. no. 127609) was obtained from BioLegend. The rabbit polyclonal anti-histone $\mathrm{H} 3$ (citrulline R2 + R8 + R17; H3Cit; Cat. no. ab5103), mouse monoclonal anti-myeloperoxidase (anti-MPO; 2C7; Cat. no. ab25989), anti-lactoferrin antibody (2B8; Cat. no. ab10110) and anti-PAD4 (4H5; Cat. no. ab128086) antibodies were obtained from Abcam. The DreamTaq Green DNA Polymerase kit (Cat. no. EP0711) was obtained from Thermo Scientific. Endoxan- $N$-(cyclophosphamide injection) was obtained from Baxter Oncology Products. The mouse anti-GAPDH mAb (6C5; Cat. no. CB1001) was purchased from Calbiochem. The microwell plates were obtained from Thermo Fisher Scientific.

Human neutrophil isolation. The human neutrophils were isolated from the blood of healthy volunteers ${ }^{44}$. The blood was collected and mixed with acid citrate dextrose (citric acid/sodium citrate/dextrose, 3:6:4; w/w/w) in 5:1 volumetric ratio (blood/anticoagulant), followed by dextran sedimentation and hypotonic lysis to remove red blood cells. Then, the cell pellet was suspended in $2 \mathrm{ml}$ of PBS and subjected to density gradient centrifugation using Histopaque-1077 for $30 \mathrm{~min}$, $210 \mathrm{~g}$ at $4{ }^{\circ} \mathrm{C}$, after which the neutrophils settled at the bottom as a cell pellet. This pellet was washed twice with PBS for $6 \mathrm{~min}$, centrifuged at $210 \mathrm{~g}$, and re-suspended in HBSS buffer without cations containing 2\% HSA or DMEM. The cells were counted using a Neubauer chamber and the required cell density was adjusted using HBSS/DMEM. Wright and Giemsa staining was used to determine the purity of the cells, which was $>95 \%$.

Quantification of NETosis by Hoechst stain and MPO-DNA ELISA. NETosis was quantified by Hoechst stain ${ }^{32}$. The neutrophils $\left(2 \times 10^{5}\right.$ cells per $\left.\mathrm{ml}\right)$ were seeded on $13 \mathrm{~mm}$ round coverslips placed in 24-well culture plates in $500 \mu \mathrm{l}$ of DMEM with $2 \%$ HSA and allowed to adhere to the coverslips for $30 \mathrm{~min}$ at $37^{\circ} \mathrm{C}$ and $5 \% \mathrm{CO}_{2}$. Then, the cells were independently stimulated with $E$. carinatus venom $\left(5-50 \mu \mathrm{g} \mathrm{ml}^{-1}\right)$ for $180 \mathrm{~min}$ to assess the dose-dependent response. To assess the time-dependent response, the E. carinatus venom $\left(25 \mu \mathrm{g} \mathrm{ml}^{-1}\right)$ was incubated for different time intervals from 0 to $180 \mathrm{~min}$. PMA (50 nM) served as a positive control. The cells were then fixed with $4 \%$ paraformaldehyde, followed by Hoechst 33342 staining $(1: 10,000)$. For NET quantification, images were acquired on a BA410 fluorescence microscope (Motic) attached to a DS-Qi2 monochrome CMOS sensor camera (Nikon) using a CCIS EC-H Plan achromatic $\times 40 / 0.65$ objective lens and NIS-Elements D software (Version 4.3.00). The NET percentage was determined in 12 non-overlapping fields per coverslip. The images were analysed using ImageJ software. The average NET percentage was calculated from triplicate experiments. The experimenter was blinded to the treatment conditions during the analysis.

To quantify the NETs in the cell supernatant, we used a capture ELISA (Cell Death ELISA ${ }^{\text {PLUS }}$, Roche) method based on capture of the MPO-associated $\mathrm{DNA}^{53}$. NETosis was induced using either E. carinatus or N. naja venom $\left(5-50 \mu \mathrm{g} \mathrm{ml}^{-1}\right)$, as described above. PMA $(50 \mathrm{nM})$ served as a positive control. Then, the reaction mixture was centrifuged at $20 \mathrm{~g}$ for $5 \mathrm{~min}$ at room temperature and the supernatant was separated. The anti-MPO $\mathrm{mAb}(1: 200,50 \mu \mathrm{l})$ was coated onto 96 -well plates overnight at $4{ }^{\circ} \mathrm{C}$. After three washes ( $300 \mu \mathrm{l}$ each), $20 \mu \mathrm{l}$ of the reaction supernatant and $80 \mu \mathrm{l}$ of incubation buffer containing peroxidase-labelled 
a
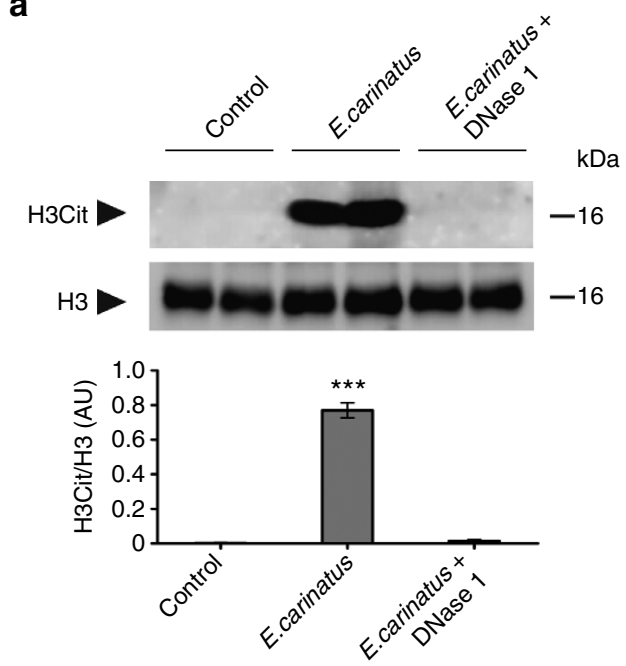

b

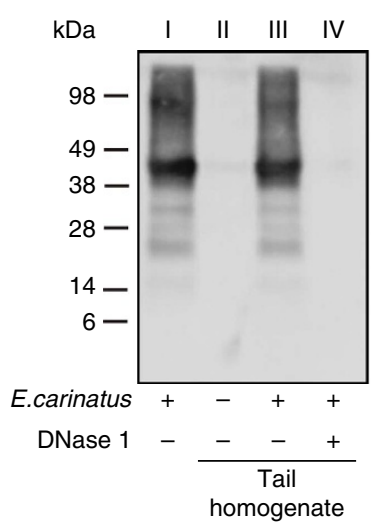

C

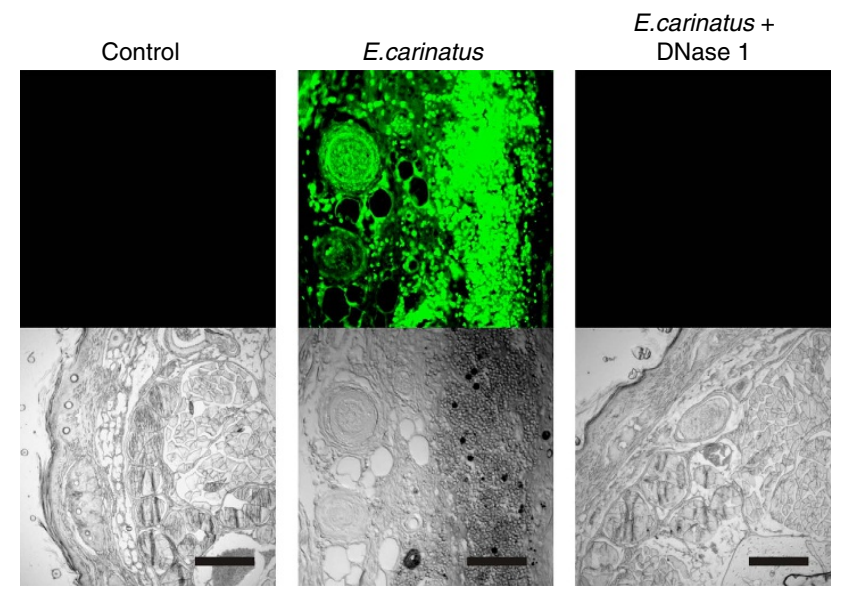

d
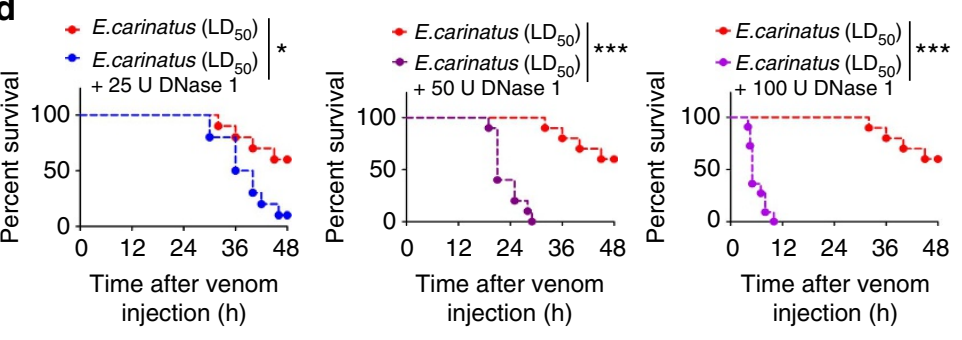

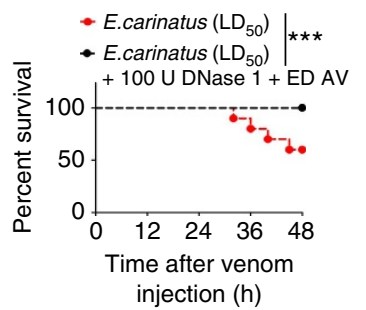

Figure 7 | Co-injection with DNase 1 prevents E. carinatus venom-induced tissue destruction. (a) Western blot analysis of the appearance of H3Cit (top) in tail tissue homogenates taken $8 \mathrm{~h}$ after $\mathrm{E}$. carinatus venom $\left(\mathrm{LD}_{50}\right)$ injection in the presence or absence of DNase 1. Quantification of H3Cit levels compared with $\mathrm{H} 3$ levels is shown (bottom). AU, arbitrary units; H3Cit, citrullinated histone 3; H3, histone 3. The data are presented as mean \pm s.e.m. $(n=4) .{ }^{\star \star \star} P<0.001$ versus control mice; one-way analysis of variance, followed by Dunnett's post-hoc test. The PVDF membranes were cut based on molecular weight of respective protein using protein molecular weight marker and then probed with respective antibodies. (b) Western blot analysis (left) of the appearance of $E$. carinatus venom in tail tissue homogenates taken $8 \mathrm{~h}$ after venom $\left(L_{50}\right)$ injection in the presence or absence of DNase 1 . E. carinatus venom $(20 \mu \mathrm{g})$ served as a positive control. The image of the corresponding Ponceau-stained PVDF membrane (right) shows E. carinatus venom, $20 \mu \mathrm{g}$ (lane I), and equal protein loading of the tail tissue homogenates (lane II-IV); $n=3$. (c) Immunofluorescence images showing the accumulation of venom toxins from E. carinatus venom ( $L D_{50}$ )-injected mouse tail tissues sections in the absence (top row, middle) or presence of DNase 1 (100 $U$; top row, right). PBS-injected tail tissue served as a control (top row, left). The corresponding DIC images of the respective tissues are also shown (bottom row). Scale bars, $100 \mu \mathrm{m}(n=3)$. (d) All the experiments in this group were performed simultaneously but the data are divided into five graphs (top three and bottom two) for clarity. Kaplan-Meier survival curves: E. carinatus venom, $\mathrm{LD}_{50}$ (red line) in all the graphs; co-injection of $E$. carinatus venom ( $L D_{50}$ ) with $25 \mathrm{U}$ DNase 1 (blue line), $50 \mathrm{U}$ DNase 1 (green line), $100 \mathrm{U}$ DNase 1 (violet line), $100 \mathrm{U}$ DNase 1 pre-incubated with $50 \mu \mathrm{M}$ actin (grey line) and $100 \mathrm{U}$ DNase 1 followed by ED AV (black line). ED AV, effective dose of antivenom. $(n=10)$. ${ }^{\star} P<0.05$, ${ }^{* \star *} P<0.001$ and NS, non-significant between groups using the Log-rank test. See Supplementary Fig. 5 for the effect of DNase 1 on the lethal potency of $E$. carinatus venom (LD).

anti-DNA mAb (1:25) were added to the wells and incubated by shaking at 300 r.p.m. for $2 \mathrm{~h}$ at room temperature. Then, the wells were washed three times (with PBS, $300 \mu \mathrm{l}$ each) and $100 \mu \mathrm{l}$ of ABTS was added. After 20 min of incubation at room temperature in the dark, the absorbance was measured at $405 \mathrm{~nm}$. To calculate NET percentage, fluorescence obtained from cells lysed with $0.5 \%$ Triton $\mathrm{X}-100$ was considered as $100 \%$ NET formation. To demonstrate venom-induced NOX-dependent and/or NOX-independent NETosis, neutrophils were independently pre-incubated with DPI $(20 \mu \mathrm{M})$ and/or DNP $(750 \mu \mathrm{M})$ for $60 \mathrm{~min}$ at $37^{\circ} \mathrm{C}$ and then incubated with E. carinatus venom $(50 \mu \mathrm{g})$ for $180 \mathrm{~min}$ at $37^{\circ} \mathrm{C}$. PMA $(50 \mathrm{nM})$ and $\mathrm{A} 23187(5 \mu \mathrm{M})$ were used as a positive control for inhibition of the NOX-dependent and NOX-independent pathways, respectively.

Detection of ROS. E. carinatus venom-stimulated ROS in neutrophils was quantified using DCFDA ${ }^{29}$. The neutrophils $\left(2 \times 10^{5}\right.$ cells per $\left.\mathrm{ml}\right)$ were incubated with increasing doses of E. carinatus venom $\left(5-50 \mu \mathrm{g} \mathrm{ml}^{-1}\right)$ for $30 \mathrm{~min}$ at $37^{\circ} \mathrm{C}$. After incubation, DCFDA $(10 \mu \mathrm{M})$ was added to determine ROS. The fluorescence was measured at $530 \mathrm{~nm}$ after exciting at $480 \mathrm{~nm}$ by using Varioskan multimode plate reader (Thermo Scientific) and expressed as pmol DCF formed per mg protein. Further to demonstrate venom-induced NOX-dependent and/or NOX-independent ROS production, neutrophils were independently pre-incubated with DPI $(20 \mu \mathrm{M})$ and/or DNP $(750 \mu \mathrm{M})$ for $60 \mathrm{~min}$ at $37^{\circ} \mathrm{C}$ and then stimulated with E. carinatus venom $(50 \mu \mathrm{g})$ for $30 \mathrm{~min}$ at $37^{\circ} \mathrm{C}$. PMA $(50 \mathrm{nM})$ and $\mathrm{A} 23187$ $(5 \mu \mathrm{M})$ were used as a positive control.

Immunocytochemistry. Neutrophils $\left(2 \times 10^{5}\right.$ cells per ml) were seeded on $13 \mathrm{~mm}$ round coverslips placed in 24-well culture plates in $500 \mu$ l of DMEM with $2 \%$ HSA and allowed to adhere to the coverslips for $30 \mathrm{~min}$ at $37^{\circ} \mathrm{C}$ and $5 \% \mathrm{CO}_{2}$. Then, the cells were independently stimulated with PMA $(50 \mathrm{nM})$ and the E. carinatus venom 
a

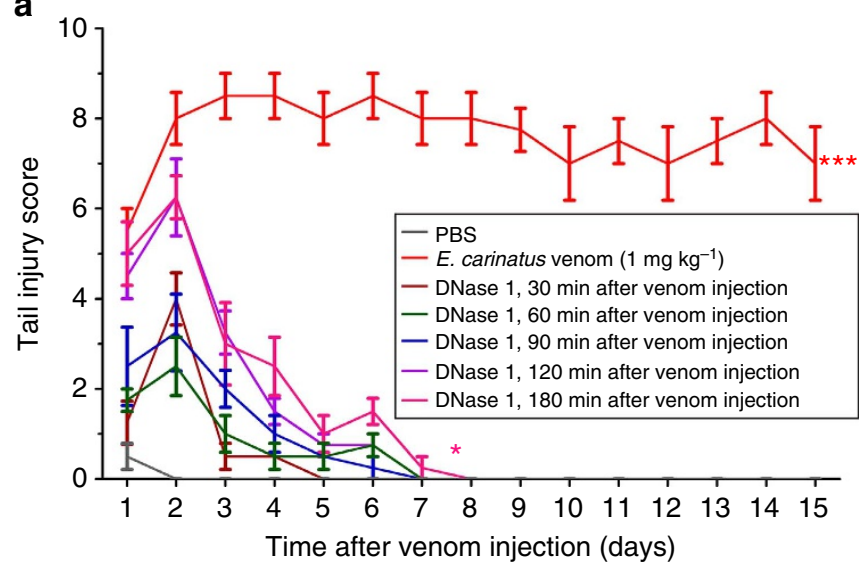

b

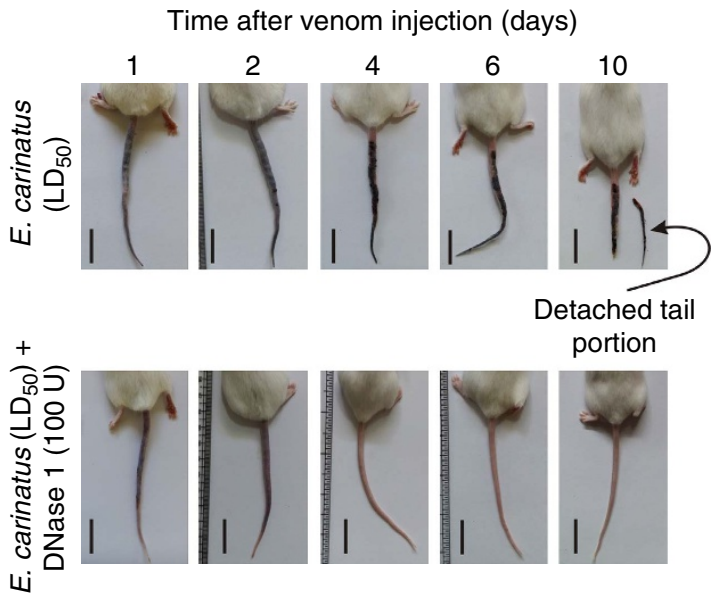

Figure 8 | DNase 1 treatment prevents $E$. carinatus venom-induced tissue destruction in the challenge study. (a) The graph represents the continued high injury score in E. carinatus venom $\left(L_{50}\right)$-injected mouse tails (red line), whereas the administration of $100 \mathrm{U}$ DNase 1 at various times (30-180 min post-venom injection) decreased the tail injury score. The data are presented as mean \pm s.e.m. $(n=10)$. ${ }^{\star} P<0.05,{ }^{\star \star \star} P<0.001$ versus PBS injected control mice; one-way analysis of variance, followed by Dunnett's post-hoc test. (b) Representative photographs of mice taken on different days after injection. The mice were injected with $E$. carinatus venom $\left(\mathrm{LD}_{50}\right.$; top row) or co-injected with $E$. carinatus venom $\left(\mathrm{LD}_{50}\right)$ and DNase 1 (100 U; bottom row); the mice in the latter group recovered and normal tail morphology was restored on day 4 onwards (bottom, third). Scale bars, $2 \mathrm{~cm}(n=10)$.

(25 and $50 \mu \mathrm{g} \mathrm{ml}^{-1}$ ) for $2.5 \mathrm{~h}$, fixed using $4 \%$ paraformaldehyde, permeabilized using $1 \%$ Triton X-100 and blocked with $1 \%$ bovine serum albumin for $1 \mathrm{~h}$ at room temperature. The cells were incubated with a primary antibody against $\mathrm{H} 3 \mathrm{Cit}$ $(1: 1,000)$ overnight at $4{ }^{\circ} \mathrm{C}$ and then with AlexaFluor 488-conjugated goat anti-rabbit $\operatorname{IgG}(1: 1,500)$ for $2 \mathrm{~h}$ at room temperature. Hoechst $33342(1: 10,000)$ was used to stain for DNA. The images were acquired on a BA410 fluorescence microscope (Motic) attached to a DS-Qi2 monochrome CMOS sensor camera (Nikon) using a CCIS EC-H Plan Achromatic $\times 20$ or $\times 40 / 0.65$ objective lens and NIS-Elements D software (Version 4.3.00 64-bit). Images were analysed using the ImageJ software

Scanning electron microscopy. Neutrophils $\left(2 \times 10^{5}\right.$ cells per $\mathrm{ml}$ in $500 \mu \mathrm{l}$ DMEM with $2 \% \mathrm{HSA}$ ) were seeded on $13 \mathrm{~mm}$ round coverslips, placed in 24-well culture plates and allowed to attach to the coverslips for $30 \mathrm{~min}$ at $37^{\circ} \mathrm{C}$. The neutrophils were then stimulated with E. carinatus venom $\left(50 \mu \mathrm{g} \mathrm{ml}^{-1}\right)$ for $2.5 \mathrm{~h}$ at $37^{\circ} \mathrm{C}$, fixed in $2.5 \%$ glutaraldehyde and post-fixed in $0.5 \%$ osmium tetroxide for $30 \mathrm{~min}$. Then, the coverslips were incubated in $1 \%$ tannic acid for $30 \mathrm{~min}$, with $0.5 \%$ osmium tetroxide for $30 \mathrm{~min}$ and dehydrated with a graded series of alcohol (30-100\%) for $5 \mathrm{~min}$ each. The coverslips were dried in a desiccator for $24 \mathrm{~h}$ and the coverslips containing specimens were coated with a carbon layer using a thin layer evaporator. The samples were visualized using a Zeiss EVO LS15 scanning electron microscope.

Venom-induced mouse tail tissue destruction and lethality. E. carinatus or $N$. naja venom ( $\mathrm{LD}_{50} / \mathrm{LD}$ dissolved in $\left.50 \mu \mathrm{PBS}\right)$ was subcutaneously administered to the groups of mice $(n=10) 3 \mathrm{~cm}$ distal to the base of the tail. The lethal dose of venom was determined in a pilot study (E. carinatus venom $\mathrm{LD}_{50}=1 \mathrm{mg}$ per $\mathrm{kg}$ body weight and $\mathrm{LD}=1.5 \mathrm{mg}$ per $\mathrm{kg}$ body weight and $N$. naja venom $\mathrm{LD}=0.75 \mathrm{mg}$ per kg body weight). The time of death and tail injuries were recorded for each mouse. The severity of the tail injury was judged visually and scored according to a 10 point scale; $0=$ no injury, $1=$ oedema, $2=$ oedema with minor haemorrhage, $4=$ oedema with haemorrhage causing less than $25 \%$ tail discolouration, $6=$ oedema and major haemorrhage or wound causing $25-50 \%$ tail discolouration, $8=$ oedema and major haemorrhage or wound causing $50-75 \%$ tail discolouration, $10=$ oedema and major haemorrhage or wound causing more than $75 \%$ tail discolouration. The tail injury observations were recorded every day for 15 days after venom injection. To assess the effects of DNase 1 on tail haemorrhage, E. carinatus venom $\left(\mathrm{LD}_{50} / \mathrm{LD}\right)$ was co-injected independently with 25,50 or $100 \mathrm{U}$ DNase 1. In the challenge study, $100 \mathrm{U}$ DNase 1 was administered $\sim 5 \mathrm{~mm}$ distal to the venom injection site $30,60,90,120$ or $180 \mathrm{~min}$ after the E. carinatus venom $\left(\mathrm{LD}_{50}\right)$ injection. To assess the effect of DNA on venom lethality, E. carinatus venom $\left(\mathrm{LD}_{50} / \mathrm{LD}\right)$ was incubated with calf thymus DNA in a 1:1 (w/w) ratio for $10 \mathrm{~min}$ at $37^{\circ} \mathrm{C}$ and injected subcutaneously into the tail. Appropriate controls were maintained according to the assay requirements.

Histopathological studies. The venom-induced tail tissue destruction and the presence of NETs in the venom-injected tail tissues were examined in H\&E-stained tissue sections. The respective tissues were dissected from the venom injection site, fixed overnight in buffered formalin and subjected to dehydration with different grades of alcohol and chloroform mixture. The processed tissues were embedded in molten paraffin wax, and $10-\mu \mathrm{m}$-thick sections were prepared using a microtome. The sections were stained with H\&E, observed under an Axio Imager.A2 microscope (Zeiss) and photographed.

Immunohistochemistry. The localization of $\mathrm{H} 3 \mathrm{Cit}$, Ly6G/lactoferrin and DNA in mouse tail tissue was examined by immunofluorescence microscopy. The mouse tail tissue was dissected from the E. carinatus venom-injected normal and neutropenic mice, processed, embedded in solidifying paraffin wax and cut into $10-\mu \mathrm{m}$-thick cross/longitudinal sections. The sections were deparaffinized by incubating the slides overnight at $55^{\circ} \mathrm{C}$ and subjected to xylene clearance for $5 \mathrm{~min}$. Furthermore, the sections were rehydrated with different grades of alcohol $(100-50 \%)$. The antigens were retrieved by incubating the slides with Tris-EDTA buffer ( $\mathrm{pH}$ 9.0) in a steamer for $45 \mathrm{~min}$. The tissues were permeabilized using 1\% Triton X-100 and incubated with primary antibodies against H3Cit $(1: 1,000)$ overnight at $4{ }^{\circ} \mathrm{C}$, followed by incubation with an AlexaFluor 488-conjugated goat anti-rabbit IgG antibody (1:500) for $2 \mathrm{~h}$ in the dark at room temperature. The sections were then incubated with an AlexaFluor 647-conjugated anti-mouse Ly6G antibody (1:200) for $3 \mathrm{~h}$ at room temperature or anti-mouse lactoferrin antibody (1:500) for overnight at $4{ }^{\circ} \mathrm{C}$, followed by incubation with an AlexaFluor 647-conjugated goat anti-mouse IgG antibody (1:500) for $2 \mathrm{~h}$ in the dark at room temperature. Hoechst $33342\left(1: 10,000,1 \mu \mathrm{g} \mathrm{ml}^{-1}\right)$ was used to stain DNA. Images were acquired with a BA410 fluorescence microscope (Motic) attached to a DS-Qi2 monochrome CMOS sensor camera (Nikon) using a CCIS EC-H plan achromatic $\times 10 / 0.25$ and $\times 40 / 0.65$ objective lens and NIS-Elements D software (Version 4.3.00), or using a confocal microscope (Zeiss LSM 510 Meta). The appropriate controls were maintained.

The accumulation of venom toxins in E. carinatus/N. naja venom-injected tail tissues after $8 \mathrm{~h}$ of venom injection in the presence and absence of DNase 1/actin were detected using the appropriate rabbit polyclonal antibodies $\left(2 \mu \mathrm{g} \mathrm{ml}^{-1}\right)$, followed by an AlexaFluor 488-conjugated goat anti-rabbit IgG secondary antibody (1:500). The appropriate controls were maintained.

Rabbit immunization and IgG purification. Rabbits were independently immunized against $E$. carinatus and $N$. naja venoms, and IgGs were purified ${ }^{54}$ E. carinatus $(200 \mu \mathrm{g})$ or $N$. naja $(100 \mu \mathrm{g})$ venoms were diluted in $100 \mu \mathrm{l}$ PBS, thoroughly mixed with an equal volume of Freund's complete adjuvant and intradermally injected into female rabbits at several sites. Three booster doses of venom were administered at the same concentration and an equal volume of Freund's incomplete adjuvant at weekly intervals. Blood was drawn from the marginal ear vein on the ninth day after the third booster dose and allowed to coagulate for $24 \mathrm{~h}$ at $8-10^{\circ} \mathrm{C}$ to obtain the antiserum. The antiserum was subjected to ammonium sulfate precipitation to obtain the crude IgG fraction, which was then subjected to Protein A-agarose column chromatography. The column was equilibrated with PBS and $5 \mathrm{mg}$ of the crude IgG fraction in $2 \mathrm{ml}$ of PBS was loaded and eluted using $0.2 \mathrm{M}$ glycine- $\mathrm{HCl}$ buffer, $\mathrm{pH} 2.9$. After reading the optical density at $280 \mathrm{~nm}, 1 \mathrm{ml}$ aliquots were collected, pooled and then neutralized using $1 \mathrm{M}$ Tris- $\mathrm{HCl}$ buffer, $\mathrm{pH}$ 8.0. The samples were subjected to dialysis against PBS. Aliquots of antibodies with $2 \mathrm{mg} \mathrm{ml}^{-1}$ concentration were prepared and stored at $-20^{\circ} \mathrm{C}$ and used for the study. 
a
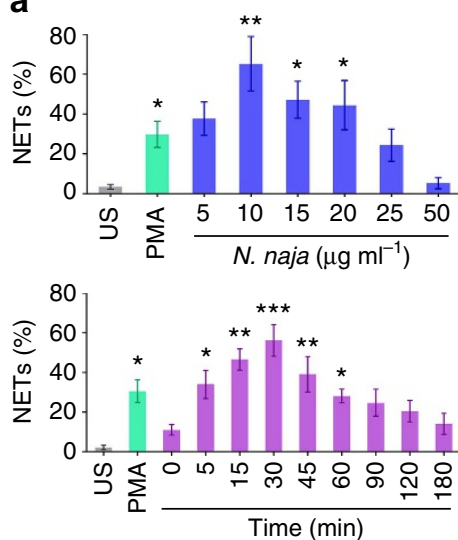

b

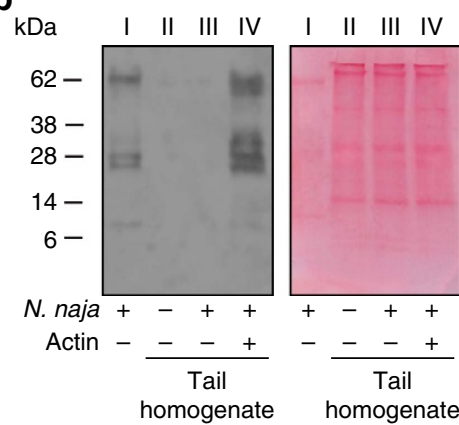

C

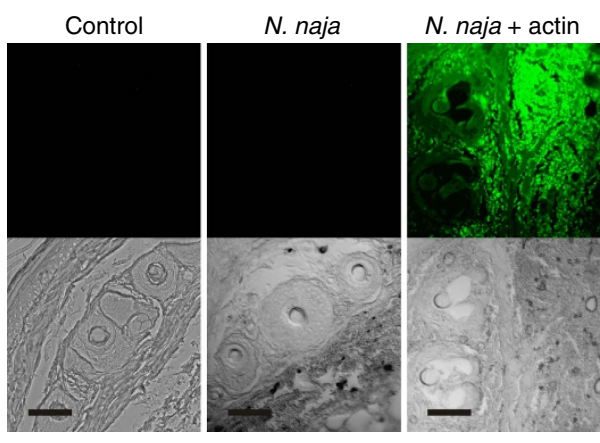

d

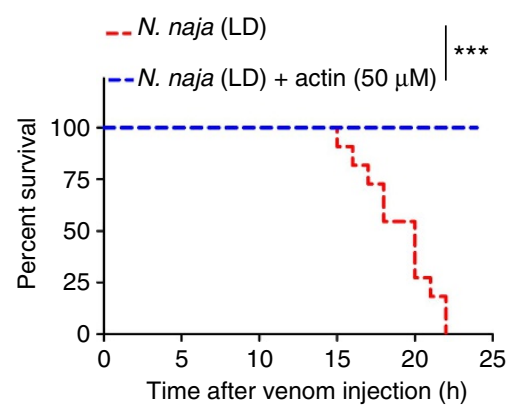

Figure 9 | DNase activity of $\boldsymbol{N}$. naja venom is essential for degrading NETs and increasing its lethal potency. (a) N. naja venom-stimulated NET formation was quantified using MPO-DNA capture ELISA in both dose- (top) and time-dependent (bottom) assays. US, unstimulated cells. The results are expressed as the percent increase relative to the US; mean \pm s.e.m. $(n=6) .{ }^{\star} P<0.05,{ }^{\star \star} P<0.01,{ }^{\star \star \star} P<0.001$ versus the US; one-way analysis of variance, followed by Dunnett's post-hoc test. PMA $(50 \mathrm{nM})$ served as a positive control. (b) Western blot analysis (left) of the appearance of $N$. naja venom in tail tissue homogenates taken $8 \mathrm{~h}$ after venom (LD) injection in the presence or absence of actin $(50 \mu \mathrm{M})$. N. naja venom (20 $\mu \mathrm{g})$ served as a positive control. The image of the corresponding Ponceau-stained PVDF membrane (right) shows N. naja venom, $20 \mu \mathrm{g}$ (lane I) and equal protein loading of tail tissue homogenates (lane II-IV); $n=3$. (c) Representative immunofluorescence images were captured $8 \mathrm{~h}$ after $N$. naja venom (LD) injection in mouse tails and did not show an accumulation of venom (top row, middle), similar to the PBS-injected control tissue (left). However, N. naja venom accumulated when the venom (LD) was pre-treated with $50 \mu \mathrm{M}$ actin before injection. The corresponding DIC images of respective tissues are shown (bottom). Scale bars, $100 \mu \mathrm{m}(n=3)$. (d) Kaplan-Meier survival curves after injections of $N$. naja venom (LD, red line) or N. naja venom (LD) pre-incubated with $50 \mu M$ actin (blue line); $n=10$. ${ }^{\star \star \star} P<0.001$; Log-rank test.

Neutropenic mouse model. Neutropenia was induced in mice using cyclophosphamide ${ }^{55}$. Briefly, female Swiss albino mice were intraperitoneally injected with cyclophosphamide in two doses totaling $250 \mathrm{mg} \mathrm{kg}^{-1}$. Initially, $150 \mathrm{mg} \mathrm{kg}^{-1}$ was administered in $500 \mu \mathrm{l}$ saline as the first dose on day 1 , and the second dose of $100 \mathrm{mg} \mathrm{kg}^{-1}$ was administered on day 4 . Blood samples were drawn from the retro-orbital plexus on days 4 and 5 , and subjected to total and differential cell counts using a Neubauer chamber and microscopic examination of Wright-stained smears. Then, the neutropenic mice were used on day 4 , where complete neutrophil depletion was found (Supplementary Table 1), to determine the tail tissue destruction activity and lethality $(n=10)$ of the E. carinatus venom $\left(\mathrm{LD}_{50}\right)$ in the presence and absence of DNase $1(100 \mathrm{U})$ as described above.

Western blot analysis. In the ex vivo experiment, the levels of $\mathrm{H} 3 \mathrm{Cit}$, histone $\mathrm{H} 3$ and PAD4 in human neutrophils incubated with 5,25 and $50 \mu \mathrm{g} \mathrm{ml}^{-1}$ of E. carinatus venom for $2.5 \mathrm{~h}$ at $37^{\circ} \mathrm{C}$ were observed by western blotting. In the in vivo studies, the levels of $\mathrm{H} 3 \mathrm{Cit} / \mathrm{histone} \mathrm{H} 3 / \mathrm{MPO}$ were determined in mice tail homogenates. The mice were divided into three different treatment groups: (i) E. carinatus venom $\left(\mathrm{LD}_{50}\right)$ was injected into the mice at different time intervals $\left(2,4,8,16\right.$ and $12 \mathrm{~h} ; 3$ and 10 days); (ii) E. carinatus venom $\left(\mathrm{LD}_{50}\right)$ was injected into normal and neutropenic mice for $8 \mathrm{~h}$ and (iii) E. carinatus venom $\left(\mathrm{LD}_{50}\right)$ was injected into mice in the presence or absence of DNase $1(100 \mathrm{U})$ for $8 \mathrm{~h}$. The accumulation of venom in tail tissue was observed using western blots of tail tissue homogenates from mice injected with E. carinatus venom $\left(\mathrm{LD}_{50}\right)$ in the presence or absence of DNase $1(100 \mathrm{U})$ and mice injected with $N$. naja venom in the presence or absence of actin $(50 \mu \mathrm{M}) 8 \mathrm{~h}$ after injection using rabbit raised polyclonal antibodies raised against respective snake. Briefly, the treated human neutrophils and mouse tail portions $(3 \mathrm{~cm}$ length of tail, with the injection site at the centre, were collected after the mice were anaesthetized and killed at the indicated time intervals in the respective experiments) were snap frozen and homogenized in RIPA buffer with protease inhibitor cocktails on ice. The homogenates were centrifuged at $15,000 \mathrm{~g}$ for $15 \mathrm{~min}$ at $4{ }^{\circ} \mathrm{C}$ and equal amounts of protein were fractionated on SDS-PAGE and electroblotted onto polyvinylidene difluoride (PVDF) membranes. The blots were then incubated with primary antibodies (anti-H3Cit (1:750), anti-H3 (1:750), anti-PAD4 (1:2,000), anti-MPO (1:750), anti-E. carinatus $\left(2 \mu \mathrm{g} \mathrm{ml}^{-1}\right)$ and anti-N. naja $\left.\left(2 \mu \mathrm{g} \mathrm{ml}^{-1}\right)\right)$ overnight at $4^{\circ} \mathrm{C}$ and subsequently with the appropriate horseradish peroxidase-conjugated secondary antibody $(1: 5,000)$ for $2 \mathrm{~h}$ at room temperature. The blots were developed with an enhanced chemiluminescence substrate and visualized (Alliance 2.7, Uvitec). To confirm equal loading, the glyceraldehyde 3-phosphate dehydrogenase (GAPDH) levels were observed by incubating the membrane with an anti-GAPDH antibody $(1: 1,000)$. For the venom accumulation study, the electroblotted membranes were stained with Ponceau to confirm equal protein loading. ImageJ software was used to quantify the blots. Images have been cropped for presentation. Uncropped images are presented in Supplementary Fig. 11.

Detection of DNase activity of the venom. The DNase activity of the venom was determined by agarose gel electrophoresis/DNase radial diffusion assay. Briefly, $750 \mathrm{ng}$ of calf thymus DNA was independently incubated with the N. naja $\left(5-50 \mu \mathrm{g} \mathrm{ml}^{-1}\right)$ venom for $60 \mathrm{~min}$, at $37^{\circ} \mathrm{C}$ in a final volume of $50 \mu \mathrm{l} \mathrm{PBS}$. The reaction mixture was subjected to electrophoresis on $0.8 \%$ agarose gels at $50 \mathrm{~V}$ in TAE buffer ( $40 \mathrm{mM}$ Tris-base and $1 \mathrm{mM}$ EDTA, $\mathrm{pH}$ 8.0) for $1 \mathrm{~h}$. Calf thymus DNA that had been treated with DNase $1(5 \mathrm{U})$ served as a positive control. After electrophoresis, the gel was visualized and photographed on a ultraviolet transilluminator (Alliance 2.7, Uvitec). The N. naja venom DNase activity was inhibited by incubating the sample with actin $(5-25 \mu \mathrm{M})$ for $10 \mathrm{~min}$ at $37^{\circ} \mathrm{C}$. Image has been cropped for presentation. Uncropped image is presented in Supplementary Fig. 11.

For radial diffusion assay, molten agarose $(5 \mathrm{ml}, 2.1 \%)$ containing herring sperm DNA $\left(1 \mathrm{mg} \mathrm{ml}^{-1}\right)$ and ethidium bromide $\left(1 \mu \mathrm{g} \mathrm{ml}^{-1}\right)$ was poured into wells of six-well culture plates and allowed to solidify. Seven-millimetre diameter 
wells were created at the centre of the dishes and loaded with $E$. carinatus venom (50-500 $\mu$ g per well) for $24 \mathrm{~h}$ at $37^{\circ} \mathrm{C}$. DNase $1(10 \mathrm{U})$ served as the positive control. After incubation, the plates were visualized and photographed on a ultraviolet transilluminator (Alliance 2.7, Uvitec).

Effect of $\boldsymbol{E}$. carinatus venom on serum DNase activity. Serum DNase activity was determined using the radial diffusion method. Molten agarose $(5 \mathrm{ml}, 2.1 \%)$ containing herring sperm DNA $\left(1 \mathrm{mg} \mathrm{ml}^{-1}\right)$ and ethidium bromide $\left(1 \mu \mathrm{g} \mathrm{ml}^{-1}\right)$ was poured into $35 \mathrm{~mm}$ diameter Petri dishes and allowed to solidify. Seven-millimetre diameter wells were created at the centre of the dishes and loaded with human serum $(200 \mu \mathrm{l})$, which was independently pre-incubated with 250 , 500 and $1,000 \mu \mathrm{g}$ of E. carinatus venom for $1 \mathrm{~h}$ at $37^{\circ} \mathrm{C}$. DNase $1(10 \mathrm{U})$ served as the positive control. After $24 \mathrm{~h}$ of incubation at $37^{\circ} \mathrm{C}$, the plates were visualized and photographed on a ultraviolet transilluminator (Alliance 2.7, Uvitec).

DNA-venom capture ELISA. The interaction between DNA and E. carinatus venom was studied using DNA-venom capture ELISA with Cell Death ELISA ${ }^{\text {PLUS }}$ Roche. Neutrophils $\left(1 \times 10^{5}\right.$ cells per $\left.500 \mu \mathrm{l}\right)$ were incubated with $E$. carinatus venom $(25,50$ and $100 \mu \mathrm{g})$ for $2.5 \mathrm{~h}$ to ensure NET formation and binding of the E. carinatus venom to NET DNA. Next, the DNA-histone complex provided in the assay kit $(40 \mu \mathrm{l})$ was incubated with $E$. carinatus venom $(50 \mu \mathrm{g})$ in a final volume of $500 \mu \mathrm{l}$ made up with incubation buffer for $2.5 \mathrm{~h}$ to serve as a positive control. The concentrations of the DNA-histone complex and E. carinatus were determined in our pilot study, where $40 \mu \mathrm{l}$ of the DNA-histone complex bound to a maximum of $50 \mu \mathrm{g}$ of $E$. carinatus venom. After incubation, the samples were centrifuged at $20 \mathrm{~g}$ for $5 \mathrm{~min}$ at room temperature, and $20 \mu \mathrm{l}$ of the supernatant was added to streptavidin-coated 96-well plates, along with $80 \mu \mathrm{l}$ of an anti-histone-biotin antibody (1:20) for $2 \mathrm{~h}$, followed by shaking at 300 r.p.m. at room temperature. The plate was washed (three times with incubation buffer, $300 \mu \mathrm{l}$ each) and incubated with a rabbit polyclonal antibody against $E$. carinatus venom $(1: 1,000)$ for $2 \mathrm{~h}$, followed by shaking at 300 r.p.m. at room temperature. Then, the plate was washed (three times with incubation buffer, $300 \mu \mathrm{l}$ each) and incubated with an horseradish peroxidase-conjugated anti-rabbit secondary antibody $(1: 5,000)$ for $2 \mathrm{~h}$ by shaking at 300 r.p.m. at room temperature in the dark. The wells were again washed (three times with incubation buffer, $300 \mu \mathrm{l}$ each) and $100 \mu \mathrm{l}$ of the ABTS peroxidase substrate was added. After $20 \mathrm{~min}$ of incubation at room temperature in the dark, the absorbance was measured at $405 \mathrm{~nm}$ using Varioskan multimode plate reader (Thermo Scientific). The percent increase in the absorbance with respect to the control indicated the binding of E. carinatus venom toxins to the DNA-histone complex or NETs.

Detection of DNA-venom interaction by non-denaturing PAGE. The interaction between DNA and E. carinatus venom was also studied by electrophoresis. We used the amplified PCR product ( $160 \mathrm{bp}$ ) that was produced by multiplex PCR using the mecA P4 (5' ${ }^{\prime}$-TCCAGATTACAACTTCACCAGG-3') and mecA P7 $\left(5^{\prime}\right.$-CCACTTCATATCTTGTAACG- $\left.{ }^{\prime}\right)$ primers as previously described ${ }^{56}$. The reaction was carried out with a DreamTaq Green DNA Polymerase kit consisting of $200 \mu \mathrm{M}$ dNTPs, $1.25 \mathrm{U}$ DreamTaq DNA polymerase and $100 \mathrm{ng}$ template DNA (Genomic source S. aureus). PCR amplification was performed in a Surecycler 8800 (Agilent Technologies) using the following conditions: initial denaturation for $15 \mathrm{~min}$ at $95^{\circ} \mathrm{C} ; 35$ cycles consisting of denaturation for $30 \mathrm{~s}$ at $95^{\circ} \mathrm{C}$, annealing for $30 \mathrm{~s}$ at $53^{\circ} \mathrm{C}$, elongation for $1 \mathrm{~min}$ at $72^{\circ} \mathrm{C}$ and post-extension for $5 \mathrm{~min}$ at $72^{\circ} \mathrm{C}$. The amplified fragment/amplicon $(250 \mathrm{ng})$ was incubated with increasing concentrations of E. carinatus venom $(5-50 \mu \mathrm{g})$ for $1 \mathrm{~h}$ at $37^{\circ} \mathrm{C}$ in a final reaction volume of $20 \mu$ l. Then, the reaction mixture was separated on non-denaturing PAGE $(7.5 \%)$ using $0.5 \times$ Tris-borate-EDTA buffer, $\mathrm{pH} 8.5$, with a constant voltage of $50 \mathrm{~V}$ for $4 \mathrm{~h}$. The gel was visualized on a ultraviolet transilluminator (Alliance 2.7 Uvitec) after staining with ethidium bromide $\left(1 \mu \mathrm{g} \mathrm{ml}^{-1}\right)$ for $30 \mathrm{~min}$ at room temperature.

The interaction between the DNA and the E. carinatus venom was disrupted by the addition of an equal amount of chloroform and isoamyl alcohol (24:1, v/v) followed by two volumes of pre-chilled isopropanol and incubation overnight at $-20^{\circ} \mathrm{C}$. The samples were then centrifuged at $18,000 \mathrm{~g}$ for $10 \mathrm{~min}$ and the pellets were dissolved in sterile distilled water and resolved on a non-denaturing PAGE gel as described above. Images have been cropped for presentation. Uncropped images are presented in Supplementary Fig. 11.

Protein concentration measurement. The protein concentrations were determined using the method described by Lowry et al. ${ }^{57}$.

Statistics. The data are presented as the mean \pm s.e.m. of at least three independent experiments and were analysed using a two-tailed Student's $t$-test (unpaired), one-way analysis of variance, followed by Dunnett's post-hoc test or Bonferroni post hoc test for multiple comparisons as applicable. Lethality was analysed using the log-rank test after constructing Kaplan-Meier curves. All analyses were done using GraphPad Prism software (Version 5.0). The results were considered significant when $P<0.05$.

\section{References}

1. Warrell, D. A. Snake bite. Lancet 375, 77-88 (2010).

2. Williams, D. The global snake bite initiative: an antidote for snake bite. Lancet 375, 89-91 (2010).

3. WHO. Snakebites. Neglected Tropical Diseases. Preprint at http://www.who.int/ neglected_diseases/diseases/snakebites/en/ (2009).

4. Girish, K. S. \& Kemparaju, K. Overlooked issues of snakebite management: time for strategic approach. Curr. Top. Med. Chem. 11, 2494-2508 (2011).

5. Herrera, C. et al. Tissue localization and extracellular matrix degradation by PI, PII and PIII snake venom metalloproteinases: clues on the mechanisms of venom-induced hemorrhage. PLoS Negl. Trop. Dis. 9, 1-20 (2015).

6. Girish, K. S., Shashidharamurthy, R., Nagaraju, S., Gowda, T. V. \& Kemparaju, K. Isolation and characterization of hyaluronidase a 'spreading factor' from Indian cobra (Naja naja) venom. Biochimie 86, 193-202 (2004),

7. Mahadeswaraswamy, Y. H., Manjula, B., Devaraja, S., Girish, K. S. \& Kemparaju, K. Daboia russelli venom hyaluronidase: purification, characterization and inhibition by -3- ( 3-hydroxy-4-oxopyridyl ) -aminopropionic acid. Curr. Top. Med. Chem. 11, 2556-2565 (2011).

8. Girish, K. S., Jagadeesha, D. K., Rajeev, K. B. \& Kemparaju, K. Snake venom hyaluronidase: An evidence for isoforms and extracellular matrix degradation. Mol. Cell. Biochem. 240, 105-110 (2002).

9. Sunitha, K. et al. Inflammation and oxidative stress in viper bite: an insight within and beyond. Toxicon 98, 89-97 (2015).

10. Katkar, G. D. et al. Melatonin alleviates Echis carinatus venom-induced toxicities by modulating in $\mathrm{fl}$ ammatory mediators and oxidative stress. J. Pineal Res. 56, 295-312 (2014).

11. Soares, A. M. et al. Medicinal plants with inhibitory properties against snake venoms. Curr. Med. Chem. 12, 2625-2641 (2005).

12. Warrell, D. A. \& Arnett, C. The importance of bites by the saw-scaled or carpet viper (Echis carinatus): epidemiological studies in Nigeria and a review of the world literature. Acta Trop. 33, 307-341 (1976).

13. Teixeira, C. D. F. P., Fernandes, C. M., Zuliani, J. P. \& Zamuner, S. F. Inflammatory effects of snake venom metalloproteinases. Mem. Inst. Oswaldo Cruz 100, 181-184 (2005).

14. Moura-da-Silva, A. M., Butera, D. \& Tanjoni, I. Importance of snake venom metalloproteinases in cell biology: effects on platelets, inflammatory and endothelial cells. Curr. Pharm. Des. 13, 2893-2905 (2007).

15. Porto, B. N. et al. Biochemical and biological characterization of the venoms of Bothriopsis bilineata and Bothriopsis taeniata (Serpentes: Viperidae). Toxicon 50, 270-277 (2007).

16. Setubal, S. et al. Effect of Bothrops bilineata snake venom on neutrophil function. Toxicon 76, 143-149 (2013).

17. Brinkmann, V. et al. Neutrophil extracellular traps kill bacteria. Science 303, 1532-1535 (2004).

18. Fuchs, T. A., Brill, A. \& Wagner, D. D. Neutrophil extracellular trap (NET) impact on deep vein thrombosis. Arterioscler. Thromb. Vasc. Biol. 32, 1777-1783 (2012).

19. Robb, C. T., Dyrynda, E. A., Gray, R. D., Rossi, A. G. \& Smith, V. J. Invertebrate extracellular phagocyte traps show that chromatin is an ancient defence weapon. Nat. Commun. 5, 1-11 (2014).

20. Saffarzadeh, M. et al. Neutrophil extracellular traps directly induce epithelial and endothelial cell death: a predominant role of histones. PLoS ONE 7, 1-14 (2012).

21. Xu, J. et al. Extracellular histones are major mediators of death in sepsis. Nature Med 15, 1318-1321 (2009).

22. Duranton, J. et al. Effect of DNase on the activity of neutrophil elastase, cathepsin G and proteinase 3 in the presence of DNA. FEBS Lett. 473, 154-156 (2000).

23. Kaplan, M. J. \& Radic, M. Neutrophil extracellular traps: double-edged swords of innate immunity. J. Immunol. 189, 2689-2695 (2012).

24. Mahadeswaraswamy, Y. H., Nagaraju, S., Girish, K. S. \& Kemparaju, K. Local tissue destruction and procoagulation properties of Echis carinatus venom: inhibition by Vitis vinifera seed methanol extract. Phyther. Res. 22, 963-969 (2008).

25. Douda, D. N., Khan, M. A., Grasemann, H. \& Palaniyar, N. SK3 channel and mitochondrial ROS mediate NADPH oxidase-independent NETosis induced by calcium influx. Proc. Natl Acad. Sci. USA 112, 2817-2822 (2015).

26. Pilsczek, F. H et al. A novel mechanism of rapid nuclear neutrophil extracellular trap formation in response to Staphylococcus aureus. J. Immunol. 185, 7413-7425 (2010).

27. Douda, D. N., Grasemann, H., Pace-asciak, C. \& Palaniyar, N. A lipid mediator hepoxilin A3 is a natural inducer of neutrophil extracellular traps in human neutrophils. Mediators Inflamm. 2015, 1-7 (2015).

28. Stoiber, W., Obermayer, A., Steinbacher, P. \& Krautgartner, W. The role of reactive oxygen species (ROS) in the formation of extracellular traps (ETs) in humans. Biomolecules 5, 702-723 (2015).

29. Katkar, G. D. et al. Lupeol derivative mitigates Echis carinatus venom-induced tissue destruction by neutralizing venom toxins and protecting collagen and 
angiogenic receptors on inflammatory cells. Biochim. Biophys. Acta Gen. Subj 1850, 2393-2409 (2015).

30. Kolaczkowska, E. et al. Molecular mechanisms of NET formation and degradation revealed by intravital imaging in the liver vasculature. Nat. Commun. 6, 1-13 (2015).

31. Wang, Y. et al. Human PAD4 regulates histone arginine methylation levels via demethylimination. Science 306, 279-283 (2004).

32. Wong, S. L. et al. Diabetes primes neutrophils to undergo NETosis, which impairs wound healing. Nature Med 21, 815-819 (2015).

33. Kornalik, F. \& Blombäck, B. Prothrombin activation induced by Ecarin-a prothrombin converting enzyme from Echis carinatus venom. Thromb. Res. 6, 57-63 (1975).

34. Mohamed, A. H., Elserougi, M. S. \& Hanna, M. M. Observations on the effects of Echis carinatus venom on blood clotting. Toxicon 6, 215-219 (1969).

35. Varjú, I. et al. DNA, histones and neutrophil extracellular traps exert anti-fibrinolytic effects in a plasma environment. Thromb. Haemost. 113, 1289-1298 (2015).

36. Fuchs, T. A., Brill, A., Duerschmied, D., Schatzberg, D. \& Monestier, M. Extracellular DNA traps promote thrombosis. Proc. Natl Acad. Sci. USA 107, 15880-15885 (2010)

37. Longstaff, C. et al. Mechanical stability and fibrinolytic resistance of clots containing fibrin, DNA, and histones. J. Biol. Chem. 288, 6946-6956 (2013).

38. Escalante, T. et al. Role of collagens and perlecan in microvascular stability: Exploring the mechanism of capillary vessel damage by snake venom metalloproteinases. PLoS ONE 6, 1-13 (2011).

39. Escalante, T., Rucavado, A., Fox, J. W. \& Gutiérrez, J. M. Key events in microvascular damage induced by snake venom hemorrhagic metalloproteinases. J. Proteomics 74, 1781-1794 (2011).

40. Girish, K. S. \& Kemparaju, K. The magic glue hyaluronan and its eraser hyaluronidase: a biological overview. Life Sci. 80, 1921-1943 (2007).

41. Maueröder, C. et al. How neutrophil extracellular traps orchestrate the local immune response in gout. J. Mol. Med. 93, 727-734 (2015).

42. Warnatsch, A., Ioannou, M., Wang, Q. \& Papayannopoulos, V. Neutrophil extracellular traps license macrophages for cytokine production in atherosclerosis. Science 349, 316-320 (2015).

43. Brinkmann, V. \& Zychlinsky, A. Neutrophil extracellular traps: Is immunity the second function of chromatin? J. Cell Biol. 198, 773-783 (2012).

44. Halverson, T. W. R., Wilton, M., Poon, K. K. H., Petri, B. \& Lewenza, S. DNA is an antimicrobial component of neutrophil extracellular traps. PLoS Pathog. 11, $1-23$ (2015).

45. Kang, T. S. et al. Enzymatic toxins from snake venom: Structural characterization and mechanism of catalysis. FEBS J. 278, 4544-4576 (2011).

46. Kemparaju, K., Prasad, B. N. \& Gowda, V. T. Purification of a basic phospholipase A2 from Indian saw-scaled viper (Echis carinatus) venom: characterization of antigenic, catalytic and pharmacological properties. Toxicon 32, 1187-1196 (1994).

47. Utkin, Y. N. Three-finger toxins, a deadly weapon of elapid venom-Milestones of discovery. Toxicon 62, 50-55 (2013).

48. Kini, R. M. Excitement ahead: structure, function and mechanism of snake venom phospholipase A2 enzymes. Toxicon 42, 827-840 (2003).

49. Mulcahy, H., Charron-Mazenod, L. \& Lewenza, S. Extracellular DNA chelates cations and induces antibiotic resistance in Pseudomonas aeruginosa biofilms. PLoS Pathog. 4, 1-12 (2008).

50. Markland, F.S. Jr \& Swenson, S. Snake venom metalloproteinases. Toxicon 62, 3-18 (2013).

51. Farrera, C. \& Fadeel, B. Macrophage clearance of neutrophil extracellular traps is a silent process. J. Immunol. 191, 2647-2656 (2013)

52. Shashidharamurthy, R., Jagadeesha, D. K., Girish, K. S. \& Kemparaju, K. Variations in biochemical and pharmacological properties of Indian cobra (Naja naja naja) venom due to geographical distribution. Mol. Cell. Biochem. 229, 93-101 (2002)

53. Caudrillier, A. et al. Platelets induce neutrophil extracellular traps in transfusion-related acute lung injury. J. Clin. Invest. 122, 2661-2671 (2012).
54. Shashidharamurthy, R. \& Kemparaju, K. Region-specific neutralization of Indian cobra (Naja naja) venom by polyclonal antibody raised against the eastern regional venom: A comparative study of the venoms from three different geographical distributions. Int. Immunopharmacol. 7, 61-69 (2007).

55. Zuluaga, A. F. et al. Neutropenia induced in outbred mice by a simplified low-dose cyclophosphamide regimen: characterization and applicability to diverse experimental models of infectious diseases. BMC Infect. Dis. 10, 1-10 (2006).

56. Oliveira, D. C. \& de Lencastre, H. Multiplex PCR strategy for rapid identification of structural types and variants of the mec element in methicillin-resistant Staphylococcus aureus. Antimicrob. Agents Chemother. 46, 2155-2161 (2002).

57. Lowry, O. H., Roseborough, N. J., Farr, A. L. \& Randall, R. J. Protein measurement using folin-phenol reagent. J. Biol. Chem. 193, 265-275 (1951).

\section{Acknowledgements}

K.K. thanks Professor T. V. Gowda, DOS in Biochemistry (Retired), University of Mysore, Mysuru, India, Professor P. S. Sastry, Department of Biochemistry (Retired) Indian Institute of Science, Bengaluru, India, and Professor Ram Rajasekharan, Director, AcSIR, CSIR-CFTRI, Mysuru for their support. G.D.K. thanks Professor Volker Brinkmann, Max Planck Institute for Infection Biology, Germany, for his kind suggestions for immunostaining, University Grants Commission, New Delhi, India, for the research fellowship and volunteers for blood donation. We thank

Dr H. Krishnamurthy, Flow Cytometry and Confocal Microscopy Facilities, NCBS, TIFR, C-CAMP, Bengaluru, India, and Dr S. Chandranayaka, for their kind help in imaging facilities. We also thank Ms Mahitha Shree A., Mr Akshay V., Mr Madhusudan, Mr Yogesh, Mr Poornachandra Rao and Ms Deepthi for their kind help during the study. We thank Institution of Excellence (IOE), University of Mysore, Mysuru, India, for providing central instrumentation facilities. K.K. acknowledges the funding from the DBT (No.BT/PR5323/MED/30/818/2012), UGC-SAP (No. F3-14/ 2012 SAP-II) and VGST [VGST/K-FIST (2010-11)/GRD-36/2013-14]. K.S.G. acknowledges the funding from the DST (DST-SERB/LS-952/2012). The funders had no role in designing and analysis of data, decision to publish or preparation of the manuscript.

\section{Author contributions}

K.K., K.S.G. and G.D.K. conceived the idea, designed the research, discussed the data and wrote the paper; G.D.K. and M.S.S. performed the experiments, collected the data and analysed the data. M.S.S. and S.D. analysed and discussed some data. S.K.N., R.D.S., M.P., G.J.V. and B.S. performed some experiments.

\section{Additional information}

Supplementary Information accompanies this paper at http://www.nature.com/ naturecommunications

Competing financial interests: The authors declare no competing financial interests

Reprints and permission information is available online at http://npg.nature.com/ reprintsandpermissions/

How to cite this article: Katkar, G. D. et al. NETosis and lack of DNase activity are key factors in Echis carinatus venom-induced tissue destruction. Nat. Commun. 7:11361 doi: $10.1038 /$ ncomms11361 (2016).

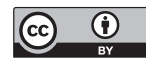

This work is licensed under a Creative Commons Attribution 4.0 International License. The images or other third party material in this article are included in the article's Creative Commons license, unless indicated otherwise in the credit line; if the material is not included under the Creative Commons license, users will need to obtain permission from the license holder to reproduce the material. To view a copy of this license, visit http://creativecommons.org/licenses/by/4.0/ 